\title{
Patient-Provider Language Concordance and Health Outcomes: A Systematic Review, Evidence Map, and Research Agenda
}

\author{
Loretta Hsueh, Adam T. Hirsh, Gerardo Maupomé, Jesse C. Stewart
}

\begin{abstract}
Although patient-provider language concordance has the potential to reduce health disparities for people with limited English proficiency, no previous work has synthesized this literature. Our systematic review sought to describe the characteristics of studies examining relationships between language concordance and health outcomes, summarize the nature of observed associations, and propose an evidence map and research agenda. A comprehensive search of published articles identified 38 quantitative studies for inclusion. Most studies were crosssectional, conducted in primary care, concentrated in Western states, and focused on Spanish speakers and physician providers. Results were split between supporting a positive association versus no association of language concordance with patient behaviors, provider behaviors, interpersonal processes of care, and clinical outcomes. Several methodological limitations were identified. Based on these results, we developed an evidence map, identified knowledge gaps, and proposed a research agenda. There is a particular need for quasi-experimental longitudinal studies with well-characterized samples.
\end{abstract}

Keywords: health disparities, language, physician/patient communication, immigrants, systematic review

This is the author's manuscript of the article published in final edited form as:

Hsueh, L., Hirsh, A. T., Maupomé, G., \& Stewart, J. C. (2019). Patient-provider language concordance and health outcomes: A systematic review, evidence map, and research agenda. Medical Care Research and Review.

https://doi.org/10.1177/1077558719860708 
2 paramount to the health of the overall U.S. population (Derose et al., 2009). The estimated 43

3 million immigrants living in the U.S. constitute $\sim 13 \%$ of the general population (Lopez \&

4 Radford, 2017) and an estimated 38 million people in the U.S. are children of at least one

5 immigrant parent. Yet, unequal access to adequate medical care continues to jeopardize the

6 health of immigrants and their children (Pew Research Center, 2013; Lopez \& Radford, 2017;

7 Derose et al. 2009).

9 of the immigrant population has limited English proficiency (LEP), defined as any person aged 5

10 years or older who reports speaking a language other than English at home and reports speaking

11 English less than 'very well' as classified by the U.S. Census Bureau (Zong \& Batalova, 2015b).

12 An additional 4.7 million people with LEP are U.S.-born, mainly to immigrant parents. In total,

13 people with LEP represent $8.5 \%$ of the U.S. population (Zong \& Batalova, 2015b). People with

14 LEP experience poorer health outcomes (Eamranond, Legedza, et al., 2009; Divi et al., 2007;

15 Gandhi et al., 2000) and a 2006 review (Jacobs et al., 2006) concluded that language barriers in 16 healthcare are associated with poor health outcomes.

17 One proposed factor for improving health for individuals with LEP is language

18 concordance in healthcare. Language concordance occurs when patients and providers

19 communicate in a shared language, whereas language discordance occurs when patients and

20 providers cannot communicate in a shared language. Healthcare providers will oftentimes rely on

21 interpreters to communicate with patients with LEP. Several systematic reviews have examined

22 the efficacy of this practice. For example, Flores (2005) examined the impact of medical

23 interpreter services on a number of health-related outcomes, including communication quality, 
24 patient satisfaction with care, and use of health services. He highlighted two main findings. First,

25 both trained (professional) interpreters and bilingual providers can have a beneficial effect on

26 quality of care. Second, relying on untrained interpreters (e.g., family members or non-physician

27 staff) is associated with inferior care. A 2007 review detected a similar pattern of results.

28 Specifically, relying on trained interpreters is associated with better clinical care compared to

29 relying on untrained interpreters, and further, relying on professional interpreters appears to raise

30 the quality of clinical care for patients with LEP to approach or equal that for patients that speak

31 English (Karliner, Jacobs, Chen, \& Mutha, 2007). In 2010, a more focused examination on the

32 impact of patient language proficiency and interpreter service use on the quality of psychiatric

33 care found that, consistent with the broader literature on medical interpreting, relying on trained

34 interpreters was associated with higher quality psychiatric care, while the use of untrained

35 interpreters was associated with more interpreter errors (Bauer \& Alegría, 2010). Finally, another

36 focused look at the impact of interpreters on palliative care quality to patients with cancer also

37 found evidence of the beneficial effect of trained interpreters on palliative care quality, with the

38 authors warning specifically against the common practice of using family members as untrained

39 interpreters (Silva et al., 2016). Overall, the evidence base supporting the use of professionally

40 trained medical interpreters is well established, and many healthcare organizations continue to

41 rely on medical interpreters. Nonetheless, a growing evidence body suggests that patients need to

42 communicate directly with a language-concordant provider to establish rapport, be satisfied with

43 their experience, and receive better medical care (Green et al., 2005b; Ngo-Metzger et al., 2007b;

44 Lee et al., 2002a). Therefore, in this review, we define language concordance as occurring when

45 patients are able to directly communicate with their providers in the patient's preferred language. 
The specific objectives of the present review are to: (1) describe the characteristics of

47 quantitative studies examining relationships between patient-provider language concordance and

48 health outcomes; (2) summarize the nature of observed associations; and (3) propose an evidence

61 effective practices are informed by rigorous, clinically relevant research. Therefore, the overall

62 aim of this review is to advance the state of the literature by distilling what is known about

63 language concordance-health outcome relationships and improving the quality of future research 64 in this area.

\section{CONCEPTUAL FRAMEWORK}

The conceptual framework in Figure 1 guides this review. We adapted the framework proposed by Kilbourne and colleagues (Kilbourne, Switzer, Hyman, Crowley-Matoka, \& Fine, 2006) for understanding the determinants of health disparities to focus on the healthcare context 
69 - specifically, patient behaviors, provider behaviors, and interpersonal processes of care. We

70 added the clinical outcomes domain, given that healthcare organizations often utilize clinical

71 outcomes as indicators of quality of care. Focusing on the healthcare context is important, as

72 patients with LEP have more negative experiences with healthcare, which may play a role in

73 their poorer health outcomes. For instance, patients with LEP are less likely to engage in health-

74 promoting behaviors, such as keeping follow-up appointments or following self-management

75 recommendations (Karter et al., 2000; Sarver \& Baker, 2000), possibly due to misunderstanding

76 instructions or poor rapport (Karliner et al., 2012; Ferguson \& Candib, 2002). Despite best

77 intentions, healthcare providers may contribute to the problem by unwittingly delivering

78 inadequate or inappropriate care. Compared to English-proficient patients, patients with LEP

79 receive fewer preventive services and health-promoting recommendations, such as diet and

80 exercise counseling (Jacobs et al., 2005; Woloshin et al., 1997; Lopez-Quintero, Berry, \&

81 Neumark, 2010). Finally, interpersonal processes of care between patients with LEP and their

82 providers may be less effective. For instance, patients with LEP are less likely to understand

83 their diagnosis, treatment, or discharge instructions (Karliner et al., 2012; Wilson et al., 2005;

84 Morales et al., 1999). Furthermore, providers who cannot speak their patients' language are more

85 likely to omit important questions or information in their discussions with their patients and are

86 more likely to misdiagnose their patients (Flores et al., 2003).

87

$88 \quad$ Search strategy and selection process

\section{METHODS}

\footnotetext{
89 We conducted a comprehensive literature search using the following terms, conjoined by 90 an OR statement: language concordance, language concordant, language discordance, language 91 discordant, linguistic concordance, linguistic concordant, linguistic discordance, linguistic
} 
92 discordant. This search was conducted in the following databases: Medline, ScienceDirect, Web

93 of Science, PsycInfo, EMBASE, and CINAHL. We also backreferenced selected articles for

94 relevant studies and reviewed titles and abstracts of studies citing selected articles in Web of

95 Science. Titles and abstracts of identified journal articles were reviewed against inclusion and

96 exclusion criteria (below) to determine initial eligibility for inclusion. The full texts of studies

97 that appeared to be eligible for inclusion were obtained and reviewed to determine final status. If,

98 after screening the title and abstract, there remained uncertainty about eligibility, full texts were

99 reviewed. For each excluded study, the reason for exclusion was recorded.

100 Inclusion and exclusion criteria

101 Studies were included if they: (1) were quantitative studies published in peer-reviewed

102 journals, (2) compared patient-provider language concordance to language discordance, (3)

103 assessed at least one health-related outcome, and (4) reported the association between language

104 concordance and at least one health outcome. For the purposes of this review, patient-provider

105 language concordance was defined as occurring when patients and providers can directly

106 communicate in the patient's preferred language ('language-concordant'), whereas language

107 discordance was defined as occurring when patients and providers cannot directly communicate

108 in the patient's preferred language ('language-discordant'). Studies were excluded if they: (1)

109 were not in English, (2) were not conducted on a U.S. sample, (3) did not include a sample with

110 LEP, (4) were exclusively qualitative in nature or not a research article (e.g., commentary), and

111 (5) achieved language concordance through interpreter use only. Non-U.S. samples were

112 excluded because this review seeks to examine the evidence for language concordance as a

113 potential mechanism underlying differences in health outcomes for U.S. immigrants. The U.S. is

114 unique among other industrialized countries in that residents lack access to universal healthcare, 
115 and the downstream consequences of disparate health insurance coverage rates and prohibitively

116 high healthcare costs likely disproportionately burden immigrants and their families.

117 Data extraction procedure

118 The first author used a standard data form to extract study descriptives (study

119 characteristics, patient characteristics, provider characteristics, language concordance

120 assessment, and outcome assessment) and study findings. Language concordance assessment

121 data include information on which informant was used to determined language concordance

122 (e.g., patient report that language concordance occurred) and how comparator groups were

123 formed. To illustrate, several studies included patients and providers that communicated through

124 an interpreter (referred throughout as 'interpreter use') in the language-discordant group.

125 Similarly, several studies sampled patients and providers that communicated directly in English

126 (referred throughout as 'English-English') and included this group in the language-concordant

127 group (grouping English-English with patients and providers that directly communicated in a

128 non-English language). We did not exclude studies for classifying interpreter use and English-

129 English as language-concordant as long as the language-concordant group included patients and

130 providers who were able to communicate directly in a shared non-English language (the

131 definition of language concordance). To capture this information, we created variables to

132 represent whether a study (1) included interpreter use in the language-discordant group (yes/no),

133 and (2) included English-English in the language-concordant group (yes/no).

134 Health outcomes were categorized into four domains. Patient behaviors were defined as

135 patient actions that indicate participation in care (e.g., medication adherence). Provider behaviors

136 were defined as provider actions that influence patient health but exclude routine assessments

137 and procedures. To illustrate, we considered outcomes such as timeliness of treatment as 
138 provider behaviors but not routine clinical procedures such as cancer screenings. Interpersonal

139 processes of care included measures of patient-provider relationship or clinical encounter quality

140 (e.g., satisfaction with care). Finally, clinical outcomes included risk factor laboratory values

141 (e.g., hemoglobin [Hb] A1c), routine assessments and procedures (e.g., vaccinations), and other

142 healthcare-relevant outcomes (e.g., length of hospitalization).

143 Study findings were coded at the level of the individual outcome. When studies reported

144 associations for individual outcomes and composite outcomes that include those individual

145 outcomes, only the individual outcomes were extracted. For example, if a study reports

146 associations for three outcomes of influenza vaccination, tetanus vaccination, and 'any

147 vaccination,' only the first two associations (influenza vaccination and tetanus vaccination) are

148 extracted.

149

\section{RESULTS}

150 The flow chart in Figure 2 depicts the study selection process. Thirty-eight studies were 151 included in the final qualitative analysis. Table 1 summarizes study descriptives, Table 2

152 presents methodological details of each of the selected studies, Table 3 summarizes main

153 findings and limitations of each of the selected studies, and Table 4 summarizes findings

154 regarding associations of language concordance with health outcomes across the selected studies.

155 Study characteristics

156 Study year, sample size, and design. Publication years ranged from 1985-2017. Over

157 three-quarters $(k=30,78.9 \%)$ included more than 200 participants. Over half $(k=21,55.2 \%)$ used

158 a cross-sectional design. This limits the literature in three ways. First, cross-sectional designs

159 cannot elucidate temporal relationships between language concordance and health outcomes.

160 Second, some outcomes (e.g., HbA1c) require longer follow-up periods to detect meaningful 
161 changes. Third, cross-sectional studies cannot account for self-selection biases that may exist 162 between patients with and without language-concordant providers.

164 with a language-discordant arm are considered unethical (Jacobs et al., 2006) and not used in this

165 literature. However, cluster-RCTs comparing 'usual care' clinics to 'intervention' clinics (i.e., 166 with specialized language-concordant care teams) are rigorous and appropriate for examining 167 these questions. Further, other rigorous designs - such as quasi-experimental longitudinal 168 designs - are feasible in hospital settings that routinely track patients and document health 169 outcomes. For example, Parker and colleagues (2017) used a quasi-experimental pre-post design 170 to examine glycemic control among Latinos with type 2 diabetes switching from a language171 discordant to a language-concordant provider. These quasi-experimental longitudinal designs 172 provide stronger evidence of causality than cross-sectional studies while keeping within the 173 bounds of ethical research.

174 Region. Over half of the studies $(k=21,55.5 \%)$ were conducted in a Western state; an 175 additional two multi-site studies included California sites. This West-dominant pattern may bias 176 knowledge about language concordance and health outcomes. This is problematic, as region177 specific factors could influence health outcomes. To illustrate, California (represented in $k=20$, $17852.6 \%$ of studies in this review) leads the most comprehensive state-level effort to prohibit 179 national origin discrimination, which includes discrimination based on language service access 180 (Youdelman, 2008). Findings from these contexts may not generalize to contexts where 181 protections are less comprehensive. This is particularly important when considering the 182 emergence of 'new immigrant destinations' - destinations previously not considered major 183 immigrant hubs that are experiencing rapid growth in their immigrant population. Certain new 
184 destinations (e.g., Raleigh-Durham, NC, and Indianapolis, IN) are experiencing immigrant 185 growth rates that triple the national rate (Singer, 2015). Further, around half of immigrants living 186 in new destinations have LEP (Terrazas, 2011). These rapid demographic changes challenge new 187 destinations to adapt their healthcare systems to deliver equitable care. In adapting, these 188 destinations become 'natural experiments' in which quasi-experimental longitudinal designs 189 could examine how the introduction of language-concordant care might influence the health of 190 their new immigrant communities.

Healthcare setting. The majority of studies $(k=21,55.2 \%)$ sampled from a general

192 outpatient/primary care clinic. An additional five (of six) multi-site/other studies sampled from a 193 general outpatient/primary care setting in addition to another setting (e.g., emergency/urgent 194 care). Thus, general outpatient/primary care clinics were represented in over half $(k=21,55.2 \%)$ 195 of the studies. As general outpatient/primary care is usually the first point of contact in 196 healthcare, continued research in these settings is critical. However, the effects of language197 concordant care in specialty settings remains understudied.

$198 \quad$ Patient characteristics

199 Age, gender, and race/ethnicity. Participants' mean/median age ranged from 29 years [6] 200 to 68 years [31]. In the 34 studies that reported gender, women were the majority in $31(81.6 \%)$. 201 The most widely represented racial/ethnic group was Hispanics/Latinos $(k=21,55.2 \%)$. Notably, 202 twelve studies (31.6\%) did not report patient race/ethnicity. In some cases, race/ethnicity could 203 be inferred through language (e.g., Vietnamese-speaking patients are likely Asian), whereas this 204 inference was more difficult with languages commonly spoken across groups (e.g., Hispanic 205 Whites and Hispanic Blacks). Race/ethnicity data are critical for characterizing samples, 
206 determining the generalizability of results, and assessing the unique and combined effects of

207 race/ethnicity and language concordance on health outcomes (National Research Council, 2004).

208 Immigrant status. While 14 studies (36.8\%) reported on immigrant status, the remaining

$209(k=24,63.2 \%)$ did not. Immigrant status is an important social determinant of health (Castañeda

210 et al., 2015) and 81\% of individuals with LEP are immigrants (Zong \& Batalova, 2015a). While

211 LEP may be a proxy for immigrant status, the two are not interchangeable. In fact, immigrant

212 status could influence the effects of language concordance on health outcomes. For example,

213 U.S.-born individuals with LEP may benefit from U.S.-citizenship status, which is linked to

214 higher health insurance coverage rates (Goldman, Smith, \& Sood, 2005). Similarly, factors

215 associated with being foreign-born may exert a health-protective effect, although evidence for

216 this 'immigrant health paradox' is mixed (Teruya \& Bazargan-Hejazi, 2013). The complex

217 relationship between immigrant status and health underscores the importance of collecting

218 immigrant status data.

219 Language spoken. Spanish was the most represented language across studies $(k=28$,

$22073.7 \%)$, followed by Chinese $(k=7,18.4 \%)$ and Vietnamese $(k=5,13.2 \%)$. According to the 2013

221 American Community Survey, 44\% of the 37 million Spanish-speaking people in the U.S. have

222 LEP. Thus, when it comes to the total number of people with LEP, Spanish ranks first. Chinese

223 ranks second with nearly 3 million speakers in the U.S., 55\% of whom have LEP. However,

224 while Vietnamese ranks fourth in total number of speakers, Vietnamese ranks first in proportion

225 of speakers who have LEP (60\%). Therefore, the likelihood that someone who speaks

226 Vietnamese also requires care in Vietnamese is greater. 
Language Concordance and Health Outcomes 11

\section{$227 \quad$ Provider characteristics}

Type. Twenty-one (55.3\%) studies specified a physician as the provider (studies using the 229 word 'provider' without further elaboration were classified as referring to physicians). Few 230 studies asked about the physician in tandem with another healthcare professional, such as a 231 nurse. As healthcare continues to adopt collaborative care models, wherein teams of diverse 232 providers care for the same patient (Reiss-Brennan et al., 2016), it becomes increasingly 233 important to acknowledge patients' relationships with non-physician providers.

234 Race/ethnicity. The vast majority $(k=30,78.9 \%)$ of studies did not report information on 235 provider race/ethnicity. The available evidence, although limited, suggests that language236 concordant providers are more racially/ethnically diverse than the general population of 237 providers (DataUSA, 2018). Racial/ethnic minority physicians are more likely to care for 238 racial/ethnic minority patients, practice in underserved areas, and care for poor patients and those 239 with Medicaid or no insurance (Cooper \& Powe, 2004) - all which tend to be characteristics of 240 populations with LEP (Kaiser Family Foundation, 2012). Likewise, minority patients prefer 241 ethnic-concordant physicians, in part, because of language and empathic treatment concerns 242 (Garcia et al., 2003; Saha et al., 2000). Further, patient-provider race concordance studies often 243 highlight the important role of language in the patient-provider relationship (Shen et al., 2017;

244 Meghani et al., 2009). The reverse is also likely - namely, that provider race/ethnicity is relevant 245 to patients in the context of patient-provider language concordance. Documenting these provider 246 demographics will aid future work comparing the relative contribution of patient-provider $247 \mathrm{racial} /$ ethnic-concordance to language-concordance on health outcomes. 
Language Concordance and Health Outcomes 12

\section{$\underline{\text { Language concordance assessment }}$}

Informant. Over a third $(k=14,36.8 \%)$ of the studies did not specify whether language concordance occurred but instead inferred that language concordance occurred. In a few cases, language concordance was inferred by study design. For example, Dunlap and colleagues (2015) [8] tested associations of language concordance with patient satisfaction and clinical understanding by comparing a Spanish-speaking pediatric surgery clinic to a general pediatric surgery clinic. Here, it is reasonable to infer that patients from the Spanish-speaking clinic received care in Spanish. However, as noted by the authors, patients in the Spanish-speaking clinic may have elected to speak English during the appointment, introducing uncertainty about the determination of language concordance.

More problematic are cases in which studies inferred that language concordance occurred because providers self-reported fluency in a language, thus assuming that clinical encounters between those providers and their patients with LEP were indeed language concordant. This approach is imprecise for two reasons. First, providers could misestimate their own language fluency (Diamond et al., 2014). Further, several studies used hospital hiring records to determine providers' self-reported fluency, and language fluency strengthens or decays over time. Second, regardless of actual language fluency, it is possible that a specific clinical encounter was conducted in English. Identifying these particular encounters as completed in a non-English language would result in misclassification. For these reasons, patient report (e.g., 'Did your provider use your language in the visit today?'), which was used in over a third $(k=14,36.8 \%)$ of the studies, is the 'gold standard' for assessing language concordance. For similar reasons, language fluency should be examined from the patient's perspective. Fernandez and colleagues (2011) [12] provide an excellent example of this practice by asking patients, "Without using an 
271 interpreter, how well does your personal physician speak your language?” and permitting

272 patients to select from a list of six responses ranging from "does not speak my language" to

273 "very well."

$274 \quad$ Classifying language-concordant and language-discordant groups. Several studies

275 included patient-provider dyads that communicated through an interpreter (classified as language

276 discordant). Multiple studies also sampled dyads that communicated directly in English

277 ('English-English'), classifying this group as language concordant. Variation in

278 inclusion/exclusion of interpreter use and English-English groups often resulted in multiple

279 comparisons, for a single outcome, within a single study. Therefore, the present results are

280 interpreted at the level of the individual outcome $(n=203)$.

281 Interpreter use dyads were most often classified as language discordant, as 116 outcomes

$282(57.1 \%)$ included them in the language-discordant group whereas only 15 outcomes $(7.4 \%)$

283 excluded them from this group, and 176 outcomes (86.7\%) excluded them from the language-

284 concordant group. The number of outcomes that classified English-English dyads as language

285 concordant $(n=103,50.7 \%)$, as compared to those that did not $(n=90,44.3 \%)$, were similar. No

286 information was provided on classification criteria for this group for $10(4.9 \%)$ outcomes. This

287 could have important implications, as English-English dyads could be inflating detected

288 associations (e.g., English-English dyads reporting better understanding their providers'

289 discharge instructions). Therefore, we conducted a subanalysis of the 90 associations from 20

290 studies that did not include English-English dyads in the language concordant group to examine

291 whether the inclusion of English-English dyads meaningfully changed the results. 
Language Concordance and Health Outcomes 14

292

293

294

295

296

297

298

299

300

301

302

303

304

305

306

307

308

309

310

311

312

313

314

\section{$\underline{\text { Outcome assessment }}$}

Patient report was used to measure 135 (66.5\%) outcomes. Only one study [5] of patientprovider agreement collected outcome measures from providers. The lack of provider-reported outcomes for interpersonal processes of care is important, as previous research demonstrates a reciprocal relationship between patients' and providers' thoughts and actions (LeBlanc et al., 2009; Street, Gordon, \& Haidet, 2007). Yet, this review indicates that providers are often excluded from the equation, thus limiting our understanding of possible mechanisms underlying patients' reported interpersonal processes of care outcomes.

\section{$\underline{\text { Associations between language concordance and patient behaviors }}$}

Patient behaviors were examined across 23 outcomes from nine studies [3, 7, 11, 18, 19, $21,24,25,34]$. Six $(26.1 \%)$ of these associations were significant and favored languageconcordant care; 17 (73.9\%) detected no association (Table 4).

Within specific patient behaviors, the evidence consistently suggests that medication adherence is not associated with patient-provider language concordance [7, 11, 24, 34]. Of note, these studies examined adherence to cardiovascular disease (CVD) or asthma medication. This pattern was found across objective and self-report adherence measures, and three [11, 24, 34] of four studies measured medication adherence longitudinally. Evidence for other adherence is mixed, with some evidence that language concordance is associated with keeping follow-up appointments for outpatient care $[21,24]$, perhaps because patients receiving languageconcordant care develop better interpersonal relationships with their providers; however, findings for diabetes self-care are mixed [7]. Finally, evidence for other patient behaviors is also mixed: there is some support for the relationship between language concordance and patientinitiated questions [19] and disclosure of complementary health approaches [3], suggesting 
315 language concordance fosters patient-initiated communication, but no association between

316 language concordance and going to a usual source of care for healthcare needs [25].

317 Associations between language concordance and provider behaviors

318 Provider behaviors were examined across 29 outcomes from eight studies [2, 4, 6, 9, 18, $31923,27,31]$. Eight (27.6\%) associations were significant and favored language-concordant care; $32021(72.4 \%)$ detected no association.

Evidence leans toward supporting no association between language concordance and

322 timeliness of treatment. However, this was assessed in two studies of patients with stroke-mimics

323 (e.g., seizures misdiagnosed as stroke; [31]) and cancer screening abnormalities [4], both of 324 which are high-stakes situations. The association remains unknown for lower-stakes situations, 325 such as increasing medication dosage for chronic conditions. Evidence leans toward supporting 326 no association between language concordance and risk factor assessment (e.g., family risk factor 327 assessment) $[2,6]$ or provision of services (e.g., providing health education) $[2,27,6,9,23]$.

328 Finally, one study [18] detected no association between language concordance and 329 overutilization of resources, but findings from this single study should be replicated.

330 Associations between language concordance and interpersonal processes of care

Outcomes related to interpersonal processes of care represented almost half $(n=97$,

$33247.8 \%$ ) of the total outcomes sample across 17 studies $[1,2,5,7,8,13,15,16,18,19,22,25$,

$33327,30,32,36,38]$. Forty-nine $(50.5 \%)$ of these associations were significant and favored

334 language-concordant care, one (1\%) was significant and did not favor language-concordant care, 335 and the remaining 47 (48.5\%) detected no association.

336 Interpersonal style includes positive relational attributes such as respect and trust, as well 337 as negative attributes such as discrimination. Evidence leaned toward supporting a positive 
338 association $[1,7,13,15,19,22,25,27,32]$; however, there was an interesting pattern wherein

339 language concordance was associated with lower perceived discrimination when asking patients

340 to specifically consider discrimination related to accent or language $[15,32]$, but not when

341 considering discrimination in general $[19,32]$. Future research could differentiate perceived

342 language discrimination versus other discrimination forms to better understand the mechanisms

343 underlying poor patient-provider relationships.

344 As can been seen in Table 4, evidence for communication/information quality (e.g., 'Did

345 you have a difficult time understanding your provider?) $[7,8,13,15,16,19,22,25,32,38]$

346 favored language concordance. Specifically, $12(66.7 \%)$ associations favored language

347 concordance $[7,8,13,15,19,22,38]$, while $6(33.3 \%)$ did not $[16,25,32]$. Evidence for

348 satisfaction (e.g., with provider) $[8,13,15,16,18,22,27,30]$ was mixed. Specifically, 7 (50\%)

349 of the associations favored language-concordant care $[8,13,15,18,22]$ and $7(50 \%)$ detected no

350 association $[13,16,18,22,27,30]$. The evidence leans towards supporting no association

351 between language concordance and shared decision-making (e.g., 'Did your provider involve

352 you in decisions?') [2, 7, 25, 32], spending enough time with the patient [1, 13, 32], and other

353 interpersonal processes of care (e.g., therapeutic alliance) [2, 5, 16, 22, 25 36]. Finally, evidence

354 leans toward supporting a positive association between language-concordant care and ratings of

355 provider's listening skills or feeling understood [13, 16, 22, 32].

$356 \quad$ Associations between language concordance and clinical outcomes

357 Clinical outcomes were examined across 54 outcomes from 17 studies $[6,10,12,14,17$,

$35818,20,23,26,28,29,30,31,33,35,37]$. Sixteen $(29.6 \%)$ of these associations were significant

359 and favored language-concordant care, four (7.4\%) were significant and did not favor language-

360 concordant care, and the remaining $34(63 \%)$ detected no association. 
Evidence consistently suggests no association between language concordance and

362 assessments and procedures $[6,10,20,23,29,31,33,37]$. Within cancer screens, however,

363 evidence suggests a possible negative relationship with colorectal cancer (CRC) screens $[9,20]$.

364 One avenue for future research is to conduct qualitative studies with patients and providers to

365 uncover reasons underlying this negative relationship. While evidence does not support an

366 association between language concordance and tetanus or flu vaccinations [10, 20], other

367 vaccinations - such as vaccinations for children - should be examined in future studies.

368 Evidence for risk factor control leaned toward supporting a positive association $[12,17$,

$36926,28]$ with evidence for improvements in glycemic control $[26,28]$ and low-density lipoprotein

370 cholesterol $[12,26,28]$ in patients with diabetes. A key next step is to determine whether this

371 important finding extends to other risk factors and chronic disease patient populations.

372 For emergency department visits/hospitalizations, evidence was mixed $[14,17,18]$ and

373 may depend on the reason for admittance. Finally, for other clinical outcomes (e.g., length of

374 hospitalization), the evidence was also mixed [14, 18, 30, 35].

$375 \quad$ Subanalysis Excluding English-English Dyads

376 Removing English-English dyads seemed to have an effect on three of the four domains,

377 but in different directions (see supplemental online Table 1). Specifically, the percentage of

378 associations in favor of language concordance decreased $9.5 \%$ for patient behaviors and $9 \%$ for

379 clinical outcomes, while the percentage of associations in favor of language concordance

380 increased $18.6 \%$ for provider behaviors (and 1.1\% for interpersonal processes of care).

381 Nevertheless, results remained split between supporting a positive association versus no

382 association of language concordance with patient behaviors ( $16.6 \%$ vs. $83.3 \%)$, provider

383 behaviors ( $46.2 \%$ vs. $53.8 \%$ ), interpersonal processes of care (51.6\% vs. $48.4 \%)$, and clinical 
384 outcomes (20.6\% vs. 67.6\%). Overall, associations across the four domains remained in the same 385 direction.

386

387

388

389

390

391

392

393

394

395

396

397

398

399

400

401

402

403

404 decision-making, and spending enough time with the patient. Conversely, the available evidence

405 leans towards supporting associations between language-concordant care and better patient

406

\section{DISCUSSION}

Studies of patient-provider language concordance and health outcomes are largely crosssectional, concentrated in Western states, conducted in primary care settings, and focused on Spanish-speaking patients and physician providers. Findings regarding the associations of language concordance with the global health outcome domains of this systematic review (patient behaviors, provider behaviors, interpersonal processes of care, and clinical outcomes) split between favoring language-concordant care (26-51\% of outcomes) and detecting no association (49-74\% of outcomes; see Table 4). Thus, at present, there is some intriguing evidence of a potential salutary effect of language-concordant care for each global health outcome domain. It should be noted that this literature is fraught with methodological limitations, some of which would increase the likelihood of obtaining null results and may explain the relatively high number of null results. Of particular relevance in this regard are inconsistencies in the definition, classification, and assessment of language concordance. It is also worth noting that there was virtually no evidence of a potential deleterious effect of language-concordant care.

At the health outcome subdomain level, the available evidence indicates that language concordance is consistently not associated with medication adherence, provision of services, or assessments and procedures. It also leans towards supporting no association between language concordance and timeliness of treatment, risk factor assessment, patient ratings of shared 
407 feeling understood, and better risk factor control. At present, evidence for the remaining

408 subdomains is either mixed or lacking. Based on these results and the methodological limitations

409 identified in this literature, we present an evidence map, identify knowledge gaps, and propose a

410 future research agenda.

411 Evidence map

412 Our evidence map presented in Figure 3 provides a roadmap of the potential relationships

413 between patient-provider language concordance and health outcomes based on the reviewed

414 evidence. The intentions of this map are to: (1) raise awareness about the existing breadth of

415 knowledge regarding language concordance-health outcome relationships, and (2) direct

416 attention to unexamined gaps in this literature. As such, the figure includes a number of potential

417 topics (in italics) for future research.

$418 \quad$ Future research agenda

419 An important finding of our review is that key methodological limitations currently

420 prevent strong scientific inferences from being drawn regarding the links between language

421 concordance and health outcomes and may be contributing to the relatively high number of null

422 results. Because we believe that a future research agenda that addresses these limitations should

423 be adopted, we propose such an agenda with specific recommendations. Overall, the most

424 important next steps are to:

425 1. Conduct quasi-experimental longitudinal studies or cluster-RCTs examining changes in health

426 outcomes following care from a language-concordant providers. The temporal relationship

427 between language concordance and health outcomes remains unknown, as the majority of studies

428 were cross-sectional in design. Quasi-experimental longitudinal studies and cluster randomized 
429 controlled trials provide stronger evidence of causality while keeping within the bounds of

430 ethical research. If not possible, collect longitudinal data for observational designs.

431 2. Increase research in 'new immigrant destinations' and with underrepresented languages. 'New

432 immigrant destinations' provide excellent opportunities to conduct quasi-experimental

433 longitudinal studies, as these destinations become 'natural experiments' in which researchers

434 could examine how the introduction of language-concordant care might influence the health of

435 the new immigrant community. Further, increasing the representation of other languages with

436 high proportions of speakers with LEP will improve the relevancy of the evidence to the general

437 population with LEP.

438 3. Exclude patients who elect to speak with their providers in English or through an interpreter.

439 The literature lacks a consistent definition of 'language-concordant care' (i.e., studies group

440 English-English and interpreter use dyads with individuals who speak directly to their providers

441 in a non-English language). Analyses excluding patients who elect to speak with their providers

442 in English or through an interpreter will clarify the extent to which these variables might be

443 influencing observed associations.

444 4. Verify language concordance and language fluency through patient report. Assessing language

445 concordance via sources other than the patients themselves introduces uncertainty about

446 assessment precision, while measuring language concordance as a dichotomous variable likely

447 masks considerable variance in language fluency. Confirming that patients understand the care

448 received in their preferred languages will help improve assessment accuracy and assure that

449 those with LEP actually receive the services they need.

450 5. Document race/ethnicity, immigrant status, and language spoken. Providing limited

451 information on these patient factors limits knowledge of the unique and combined effects of 
452 these factors and language concordance on health outcomes. Additional useful information

453 includes country of origin, length of U.S. residence, and provider sociodemographic factors.

$454 \quad 6$. Test for candidate mechanisms underlying relationships between language concordance and

455 health outcomes. Elucidating mechanisms would identify targets for interventions designs to 456 improve care for people with LEP. The reviewed evidence suggests that proximal changes in 457 interpersonal processes of care may partially mediate the relationship between language 458 concordance and downstream health outcomes. For example, decreasing patient perceptions of 459 language-based discrimination could increase patient participation in decision-making, which, in 460 turn, could result in a more acceptable treatment plan, improved treatment adherence, and better 461 clinical outcomes.

462 Particular to the last suggestion, data from qualitative studies support the importance of 463 interpersonal processes of care for patients with LEP. For example, in focus groups for Latina 464 mothers using pediatric health services, participants described associating their encounters with 465 bilingual providers with eased communication, improved understanding, and strengthened 466 rapport, whereas they associated encounters facilitated by interpreters as undermining their 467 relationship with the provider and feelings of betrayal. Further, several participants described 468 instances of humiliation and discrimination associated with their language-discordant encounters 469 (Steinberg, Valenzuela-Araujo, Zickafoose, Kieffer, \& Decamp, 2016). Similarly, in focus 470 groups with low-income Spanish-speaking women, participants receiving care in both English 471 and Spanish described associating Spanish-speaking providers with clear communication, 472 security, and trust. Further, while participants reported an appreciation for the interpretation 473 services they received when with language-discordant providers, many nevertheless associated 474 their communication with language-discordant providers to be poor, citing perceived insufficient 
475 or miscommunicated provision of health information by the provider (Simon et al., 2013). In

476 light of the reviewed evidence and these qualitative findings, there is intriguing evidence

477 suggesting improvements in interpersonal processes of care may be one mechanism linking

478 language concordance to improvements in other health outcomes. As previously described, over

479 half of the reviewed evidence used cross-sectional data, and these designs are unable to test for

480 these mechanisms. This limitation may be an important factor contributing to the conflicting

481 findings detected in this review.

$482 \quad$ Limitations of the present review

483 Several limitations should be considered. First, because we included only peer-reviewed

484 articles, publication bias is possible. Second, we did not exclude studies based on how the

485 language concordance groups were defined. As such, studies that included English-English

486 dyads and interpreter use dyads were included among selected studies. Although this allowed us

487 to raise awareness of this methodological limitation and offer a specific recommendation for

488 future studies, it likely also created ambiguity regarding the true relationship between language

489 concordance and health outcomes specifically among people with LEP. Third, there was

490 substantial heterogeneity in study quantity and quality within each examined health outcome

491 domain. While our comprehensive qualitative approach provided a critical overview of the

492 evidence base and informed our future research agenda, meta-analyses with focused research

493 questions should be considered as the literature matures (i.e., when there is a sufficient number

494 of studies in a focused area, such as medication adherence). This systematic review is designed

495 to stimulate and improve the rigor of future research so that such meta-analyses will become

496 possible. 
Language Concordance and Health Outcomes 23

497

498

499

500

501

502

503

504

505

506

507

508

509 Karliner et al., 2007; Bauer \& Alegría, 2010; Silva et al., 2016). The results of our review on

510 language-concordant care are also promising and can increase providers' awareness of the

511 potential importance of this method for providing care to people with LEP. Based on the results

512 of this review, policymakers should encourage healthcare organizations to collect information on

513 their patients' preferred languages and to adopt more rigorous methods of documenting whether

514 language-concordant care was achieved, such as by confirming with the patients rather than with 515 the providers.

$516 \quad$ Final conclusions

517

518

519

$\underline{\text { Research and clinical implications }}$

This review evaluated the state of the literature on language concordance and health outcomes, identified key limitations and gaps, proposed specific strategies to address them, and provided an organizing map of the evidence. Figure 3 provides a roadmap of the research areas that have and have not received attention, while the research agenda lays the groundwork for associated with recruiting and retaining bi- and multi-lingual healthcare providers remain. The use of professional interpreters continues to be essential, especially for less prevalent languages, and several other systematic reviews support the effectiveness of this practice (i.e., Flores, 2005;

Providing high-quality healthcare to an increasingly diverse patient population is a major

U.S. public health priority. People with LEP face significant barriers to achieving and maintaining good health. Facilitating patient-provider language concordance is one potential 
520 mechanism for addressing the significant and deleterious impact of language barriers in

521 healthcare. While the available evidence is largely mixed and limited by methodological issues,

522 there is a critical need for rigorous, clinically relevant research to enhance our understanding of

523 the importance and potential benefits of patient-provider language concordance in improving

524 healthcare and outcomes for the growing and vulnerable population of people with LEP.

525

526

527

528

529

530

531

532

533

534

535

536

537

538

539

540

541

\section{References}

Baker, D. W., Hayes, R., \& Fortier, J. P. (1998). Interpreter use and satisfaction with interpersonal aspects of care for Spanish-speaking patients. Medical Care, 36(10), 14611470. doi:Doi 10.1097/00005650-199810000-00004

Bauer, A. M., \& Alegría, M. (2010). Impact of patient language proficiency and interpreter service use on the quality of psychiatric care: a systematic review. Psychiatric Services, 61(8), 765-773.

Boudreau, A. D. A., Fluet, C. E., Reuland, C. P., Delahaye, J., Perrin, J. M., \& Kuhlthau, K. (2010). Associations of Providers' Language and Cultural Skills With Latino Parents' Perceptions of Well-Child Care. Academic Pediatrics, 10(3), 172-178.

Castañeda, H., Holmes, S. M., Madrigal, D. S., Young, M. E., Beyeler, N., \& Quesada, J. (2015). Immigration as a social determinant of health. Annu Rev Public Health, 36, 375-392. doi:10.1146/annurev-publhealth-032013-182419

Chao, M. T., Handley, M. A., Quan, J., Sarkar, U., Ratanawongsa, N., \& Schillinger, D. (2015). Disclosure of complementary health approaches among low income and racially diverse safety net patients with diabetes. Patient Education and Counseling, 98(11), 1360-1366. doi:10.1016/j.pec.2015.06.011 
542 Charlot, M., Santana, M. C., Chen, C. A., Bak, S., Heeren, T. C., Battaglia, T. A., ... Freund, K.

543

544

545

546

547

548

549

550

551

552

553

554

555

556

557

558

559

560

561

562

563 M. (2015). Impact of Patient and Navigator Race and Language Concordance on Care After Cancer Screening Abnormalities. Cancer, 121(9), 1477-1483. doi:10.1002/cncr.29221

Clark, T., Sleath, B., \& Rubin, R. H. (2004). Influence of ethnicity and language concordance on physician-patient agreement about recommended changes in patient health behavior. Patient Education and Counseling, 53(1), 87-93. doi:10.1016/S0738-3991(03)00109-5

Cooper, L. A., \& Powe, N. R. (2004). Disparities in patient experiences, health care processes, and outcomes: the role of patient-provider racial, ethnic, and language concordance: Commonwealth Fund New York, NY.

DataUSA. 2018. "Physicians \& surgeons." https://datausa.io/profile/soc/291060/\#demographics.

de Bocanegra, H. T., Rostovtseva, D., Cetinkaya, M., Rundel, C., \& Lewis, C. (2011). Quality of reproductive health services tolimited English proficient (LEP) patients. Journal of Health Care for the Poor and Underserved, 22(4), 1167-1178.

Derose, K. P., Bahney, B. W., Lurie, N., \& Escarce, J. J. (2009). Immigrants and Health Care Access, Quality, and Cost. Medical Care Research and Review, 66(4), 355-408. doi:10.1177/1077558708330425

Detz, A., Mangione, C. M., Nunez de Jaimes, F., Noguera, C., Morales, L. S., Tseng, C. H., \& Moreno, G. (2014). Language concordance, interpersonal care, and diabetes self-care in rural Latino patients. Journal of General Internal Medicine, 29(12), 1650-1656.

Diamond, L., Chung, S., Ferguson, W., Gonzalez, J., Jacobs, E. A., \& Gany, F. (2014). Relationship Between Self-assessed and Tested Non-English-language Proficiency 
564

565

566

567

568

569

570

571

572

573

574

575

576

577

578

579

580

581

582

583

584

585

586

Among Primary Care Providers. Medical Care, 52(5), 435-438.

doi:10.1097/Mlr.0000000000000102

Divi, C., Koss, R. G., Schmaltz, S. P., \& Loeb, J. M. (2007). Language proficiency and adverse events in US hospitals: a pilot study. International Journal for Quality in Health Care, 19(2), 60-67. doi:10.1093/intqhe/mz1069

Dunlap, J. L., Jaramillo, J. D., Koppolu, R., Wright, R., Mendoza, F., \& Bruzoni, M. (2015). The effects of language concordant care on patient satisfaction and clinical understanding for Hispanic pediatric surgery patients. Journal of Pediatric Surgery, 50(9), 1586-1589. doi:10.1016/j.jpedsurg.2014.12.020

Eamranond, P. P., Davis, R. B., Phillips, R. S., \& Wee, C. C. (2009). Patient-Physician Language Concordance and Lifestyle Counseling Among Spanish-Speaking Patients. Journal of Immigrant and Minority Health, 11(6), 494-498. doi:10.1007/s10903-008-9222-7

Eamranond, P. P., Davis, R. B., Phillips, R. S., \& Wee, C. C. (2011). Patient-physician Language Concordance and Primary Care Screening Among Spanish-speaking Patients. Medical Care, 49(7), 668-672. doi:10.1097/MLR.0b013e318215d803

Eamranond, P. P., Legedza, A. T. R., Diez-Roux, A. V., Kandula, N. R., Palmas, W., Siscovick, D. S., \& Mukamal, K. J. (2009). Association between language and risk factor levels among Hispanic adults with hypertension, hypercholesterolemia, or diabetes. American Heart Journal, 157(1), 53-59. doi:http://doi.org/10.1016/j.ahj.2008.08.015

Ferguson, W. J., \& Candib, L. M. (2002). Culture, language, and the doctor-patient relationship. Family Medicine, 34(5), 353-361.

Fernández, A., Quan, J., Moffet, H., Parker, M. M., Schillinger, D., \& Karter, A. J. (2017). Adherence to newly prescribed diabetes medications among insured Latino and white 
587

588

589

590

591

592

593

594

595

596

597

598

599

600

601

602

603

604

605

606

607

608

609

patients with diabetes. JAMA Internal Medicine, 177(3), 371-379.

doi:10.1001/jamainternmed.2016.8653

Fernandez, A., Schillinger, D., Grumbach, K., Rosenthal, A., Stewart, A. L., Wang, F., \& PerezStable, E. J. (2004). Physician language ability and cultural competence - An exploratory study of communication with Spanish-speaking patients. Journal of General Internal Medicine, 19(2), 167-174. doi:10.1111/j.1525-1497.2004.30266.x

Fernandez, A., Schillinger, D., Warton, E. M., Adler, N., Moffet, H. H., Schenker, Y., ... Karter, A. J. (2011). Language barriers, physician-patient language concordance, and glycemic control among insured latinos with diabetes: The diabetes study of Northern California (DISTANCE). Journal of General Internal Medicine, 26(2), 170-176. doi:10.1007/s11606-010-1507-6

Flores, G. (2005). The impact of medical interpreter services on the quality of health care: a systematic review. Medical Care Research and Review, 62(3), 255-299.

Flores, G., Laws, M. B., Mayo, S. J., Zuckerman, B., Abreu, M., Medina, L., \& Hardt, E. J. (2003). Errors in medical interpretation and their potential clinical consequences in pediatric encounters. Pediatrics, 111(1), 6-14. doi:DOI 10.1542/peds.111.1.6

Gandhi, T. K., Burstin, H. R., Cook, E. F., Puopolo, A. L., Haas, J. S., Brennan, T. A., \& Bates, D. W. (2000). Drug complications in outpatients. Journal of General Internal Medicine, 15(3), 149-154. doi:DOI 10.1046/j.1525-1497.2000.04199.x

Gany, F., Leng, J., Shapiro, E., Abramson, D., Motola, I., Shield, D. C., \& Changrani, J. (2007). Patient satisfaction with different interpreting methods: A randomized controlled trial. Journal of General Internal Medicine, 22(SUPPL. 2), 312-318. doi:10.1007/s11606-007$0360-8$ 
610 Garcia, J. A., Paterniti, D. A., Romano, P. S., \& Kravitz, R. L. (2003). Patient preferences for 611 physician characteristics in university-based primary care clinics. Ethn Dis, 13(2), 259-

612 267.

613 Goldman, D. P., Smith, J. P., \& Sood, N. (2005.) Legal status and health insurance among 614 immigrants. Health Affairs, 24(6), 1640-1653. doi: DOI 10.1377/hlthaff.24.6.1640.

615 Goncalves, M., Cook, B., Mulvaney-Day, N., Alegria, M., \& Kinrys, G. (2013). Retention in 616 617 mental health care of Portuguese-speaking patients. Transcultural Psychiatry, 50(1), 92107. doi:10.1177/1363461512474622

González, H. M., Vega, W. A., \& Tarraf, W. (2010). Health care quality perceptions among foreign-born latinos and the importance of speaking the same language. Journal of the American Board of Family Medicine, 23(6), 745-752. doi:10.3122/jabfm.2010.06.090264

621 Green, A. R., Ngo-Metzger, Q., Legedza, A. T., Massagli, M. P., Phillips, R. S., \& Iezzoni, L. I. 622 (2005). Interpreter services, language concordance, and health care quality. Experiences 623 of Asian Americans with limited English proficiency. Journal of General Internal Medicine, 20(11), 1050-1056.

625 Grumbach, K., \& Mendoza, R. (2008). Disparities in human resources: Addressing the lack of 626 diversity in the health professions. Health Affairs, 27(2), 413-422.

627 doi:10.1377/hlthaff.27.2.413

628 Hacker, K., Choi, Y. S., Trebino, L., Hicks, L., Friedman, E., Blanchfield, B., \& Gazelle, G. S. 629 (2012). Exploring the impact of language services on utilization and clinical outcomes for 630 diabetics. Plos One, 7(6). doi:10.1371/journal.pone.0038507 
631 Jacobs, E., Chen, A. H., Karliner, L. S., Agger-Gupta, N., \& Mutha, S. (2006). The need for 632 more research on language barriers in health care: A proposed research agenda. Milbank

634 Jacobs, E. A., Karavolos, K., Rathouz, P. J., Ferris, T. G., \& Powell, L. H. (2005). Limited

638 Jacobs, E. A., Sadowski, L. S., \& Rathouz, P. J. (2007). The impact of an enhanced interpreter 639 service intervention on hospital costs and patient satisfaction. Journal of General Internal Medicine, 22 Suppl 2, 306-311.

Jaramillo, J., Snyder, E., Dunlap, J. L., Wright, R., Mendoza, F., \& Bruzoni, M. (2016). The Hispanic Clinic for Pediatric Surgery: A model to improve parent-provider communication for Hispanic pediatric surgery patients. Journal of Pediatric Surgery, 51(4), 670-674. doi:10.1016/j.jpedsurg.2015.08.065

Jih, J., Vittinghoff, E., \& Fernandez, A. (2015). Patient-physician language concordance and use of preventive care services among limited english proficient latinos and asians. Public Health Reports, 130(2), 134-142.

Kaiser Commission on Medicaid and the Uninsured. (2012.) Overview of Health Coverage for Individuals with Limited English Proficiency. Retrieved from https://kaiserfamilyfoundation.files.wordpress.com/2013/01/8343.pdf

Karliner, L. S., Auerbach, A., Napoles, A., Schillinger, D., Nickleach, D., \& Perez-Stable, E. J. (2012). Language Barriers and Understanding of Hospital Discharge Instructions. Medical Care, 50(4), 283-289. doi:10.1097/MLR.0b013e318249c949 
654 Karliner, L. S., Jacobs, E. A., Chen, A. H., \& Mutha, S. (2007). Do professional interpreters

655

656

657

658

659

660

661

662

663

664

665

666

667

668

669

670

671

672

673 Leng, J., Changrani, J., \& Gany, F. (2011). Language Discordance and Testing for Latent

674

675 improve clinical care for patients with limited English proficiency? A systematic review of the literature. Health Services Research, 42(2), 727-754.

Karter, A. J., Ferrara, A., Darbinian, J. A., Ackerson, L. M., \& Selby, J. V. (2000). Selfmonitoring of blood glucose - Language and financial barriers in a managed care population with diabetes. Diabetes Care, 23(4), 477-483. doi:DOI $10.2337 /$ diacare.23.4.477

Kilbourne, A. M., Switzer, G., Hyman, K., Crowley-Matoka, M., \& Fine, M. J. (2006). Advancing health disparities research within the health care system: a conceptual framework. American Journal of Public Health, 96(12), 2113-2121.

Lasser, K. E., Mintzer, I. L., Lambert, A., Cabral, H., \& Bor, D. H. (2005). Missed appointment rates in primary care: The importance of site of care. Journal of Health Care for the Poor and Underserved, 16(3), 475-486. doi:10.1353/hpu.2005.0054

LeBlanc, A., Kenny, D. A., O'Connor, A. M., \& Legare, F. (2009). Decisional Conflict in Patients and Their Physicians: A Dyadic Approach to Shared Decision Making. Medical Decision Making, 29(1), 61-68. doi:10.1177/0272989x08327067

Lee, L. J., Batal, H. A., Maselli, J. H., \& Kutner, J. S. (2002). Effect of Spanish interpretation method on patient satisfaction in an urban walk-in clinic. Journal of General Internal Medicine, 17(8), 641-646. doi:10.1046/j.1525-1497.2002.10742.x Tuberculosis Infection Among Recent Asian and Latino Immigrants. Journal of Community Health, 36(2), 228-230. doi:10.1007/s10900-010-9301-2 
676 Lopez-Quintero, C., Berry, E. M., \& Neumark, Y. (2010). Limited English Proficiency Is a

677 Barrier to Receipt of Advice about Physical Activity and Diet among Hispanics with

678 Chronic Diseases in the United States (Reprinted from vol 109, pg 1769-1774, 2009).

679 Journal of the American Dietetic Association, 110(5), S62-S67.

$680 \quad$ doi:10.1016/j.jada.2010.03.009

681 Lopez, G., \& Radford, J. (2017). Statistical Portrait of the Foreign-Born Population in the United

682 States. Retrieved from http://www.pewhispanic.org/2017/05/03/statistical-portrait-of-

683 the-foreign-born-population-in-the-united-states-2015/\#

684 Manson, A. (1988). Language concordance as a determinant of patient compliance and

685 emergency room use in patients with asthma. Medical Care, 26(12), 1119-1128.

686 Martin, B. C., Shi, L., \& Ward, R. D. (2009). Race, gender, and language concordance in the 687 688 primary care setting. International Journal of Health Care Quality Assurance, 22(4), $340-352$.

689

Meghani, S. H., Brooks, J. M., Gipson-Jones, T., Waite, R., Whitfield-Harris, L., \& Deatrick, J. 690 691 A. (2009.) Patient-provider race-concordance: does it matter in improving minority patients' health outcomes? Ethnicity \& Health, 14(1), 107-130. doi: Pii 905567383 $10.1080 / 13557850802227031$.

693 Mehler, P. S., Lundgren, R. A., Pines, I., \& Doll, K. (2004). A community study of language 694 concordance in Russian patients with diabetes. Ethnicity and Disease, 14(4), 584-588.

695 Morales, L. S., Cunningham, W. E., Brown, J. A., Liu, H., \& Hays, R. D. (1999). Are Latinos 696 less satisfied with communication by health care providers? Journal of General Internal 697 Medicine, 14(7), 409-417. 
Language Concordance and Health Outcomes 32

698 National Research Council. 2004. Eliminating health disparities: measurement and data needs:

699

700

701

702

703

704

705

706

707

708

709

710

711

712

713

714

715

716

717 Reiss-Brennan, B., Brunisholz, K. D., Dredge, C., \& et al. (2016). Association of integrated

718

719 National Academies Press.

Ngo-Metzger, Q., Sorkin, D. H., Phillips, R. S., Greenfield, S., Massagli, M. P., Clarridge, B., \& Kaplan, S. H. (2007). Providing high-quality care for limited english proficient patients: The importance of language concordance and interpreter use. Journal of General Internal Medicine, 22(SUPPL. 2), 324-330. doi:10.1007/s11606-007-0340-z

Parker, M. M., Fernández, A., Moffet, H. H., Grant, R. W., Torreblanca, A., \& Karter, A. J. (2017). Association of patient-physician language concordance and glycemic control for limited-English proficiency Latinos with type 2 diabetes. JAMA Internal Medicine, 177(3), 380-387. doi:10.1001/jamainternmed.2016.8648

Percac-Lima, S., Milosavljevic, B., Oo, S. A., Marable, D., \& Bond, B. (2012). Patient navigation to improve breast cancer screening in Bosnian refugees and immigrants. Journal of immigrant and minority health / Center for Minority Public Health, 14(4), 727-730. doi:10.1007/s10903-011-9539-5

Pérez-Stable, E., Nápoles-Springer, A., \& Miramontes, J. M. (1997). The effects of ethnicity and language on medical outcomes of patients with hypertension or diabetes. Medical Care, 35(12), 1212-1219. doi:10.1097/00005650-199712000-00005

Pew Research Center. 2013. "Second-Generation Americans: A Portrait of the Adult Children of Immigrants." team-based care with health care quality, utilization, and cost. $J A M A, 316(8), 826-834$. doi:10.1001/jama.2016.11232 
720 Rostanski, S. K., Williams, O., Stillman, J. I., Marshall, R. S., \& Willey, J. Z. (2016). Language 721 barriers between physicians and patients are not associated with thrombolysis of stroke mimics. Neurology: Clinical Practice, 6(5), 389-396. doi:10.1212/CPJ.0000000000000287

724 Saha, S., Taggart, S. H., Komaromy, M., \& Bindman, A. B. (2000). Do patients choose 725 physicians of their own race? Health Affairs, 19(4), 76-83. doi:10.1377/hlthaff.19.4.76 726 Sanchez, G., Nevarez, T., Schink, W., \& Hayes-Bautista, D. E. (2015). Latino Physicians in the 727 728 729 730 731 United States, 1980-2010: A Thirty-Year Overview From the Censuses. Academic Medicine, 90(7), 906-912. doi:10.1097/Acm.0000000000000619

Sarver, J., \& Baker, D. W. (2000). Effect of Language Barriers on Follow-up Appointments After an Emergency Department Visit. Journal of General Internal Medicine, 15(4), 256264. doi:10.1111/j.1525-1497.2000.06469.x

Schenker, Y., Karter, A. J., Schillinger, D., Warton, E. M., Adler, N. E., Moffet, H. H., ... Fernandez, A. (2010). The impact of limited English proficiency and physician language concordance on reports of clinical interactions among patients with diabetes: the DISTANCE study. Patient Education \& Counseling, 81(2), 222-228. doi:10.1016/j.pec.2010.02.005

Sentell, T., Braun, K. L., Davis, J., \& Davis, T. (2013). Colorectal cancer screening: low health literacy and limited English proficiency among Asians and Whites in California. Journal of Health Communication, 18, 242-255. doi:10.1080/10810730.2013.825669

Shen, M. J., Peterson, E. B., Costas-Muniz, R., Hernandez, M. H., Jewell, S. T., Matsoukas, K., 741 \& Bylund, C. L. (2017). The Effects of Race and Racial Concordance on Patient- 
Language Concordance and Health Outcomes 34

742

743

744

745

746

747

748

749

750

751

752

753

754

755

756

757

758

759

760

761

762

763

764

Physician Communication: A Systematic Review of the Literature. J Racial Ethn Health Disparities. doi:10.1007/s40615-017-0350-4

Silva, M. D., Genoff, M., Zaballa, A., Jewell, S., Stabler, S., Gany, F. M., \& Diamond, L. C. (2016). Interpreting at the end of life: a systematic review of the impact of interpreters on the delivery of palliative care services to cancer patients with limited English proficiency. Journal of Pain and Symptom Management, 51(3), 569-580.

Simon, M. A., Ragas, D. M., Nonzee, N. J., Phisuthikul, A. M., Luu, T. H., \& Dong, X. Q. (2013). Perceptions of Patient-Provider Communication in Breast and Cervical CancerRelated Care: A Qualitative Study of Low-Income English- and Spanish-Speaking Women. Journal of Community Health, 38(4), 707-715. doi:10.1007/s10900-013-9668-y

Singer, A. (2015). A Typology of Immigrant Gateways, 2014.

Street, R. L., H. Gordon, and P. Haidet. 2007. "Physicians' communication and perceptions of patients: Is it how they look, how they talk, or is it just the doctor?" Social Science \& Medicine 65 (3):586-598. doi: 10.1016/j.socscimed.2007.03.036.

Steinberg, E. M., Valenzuela-Araujo, D., Zickafoose, J. S., Kieffer, E., \& Decamp, L. R. (2016). The "battle" of Managing Language Barriers in Health Care. Clinical Pediatrics, 55(14), 1318-1327. doi:10.1177/0009922816629760

Terrazas, A. 2011. "Immigrants in new-destination states.".

Teruya, S. A., \& Bazargan-Hejazi, S. (2013). The Immigrant and Hispanic Paradoxes: A Systematic Review of Their Predictions and Effects. Hispanic Journal of Behavioral Sciences, 35(4), 486-509. doi:10.1177/0739986313499004

Traylor, A. H., Schmittdiel, J. A., Uratsu, C. S., Mangione, C. M., \& Subramanian, U. (2010). Adherence to cardiovascular disease medications: Does patient-provider race/ethnicity 
765

766

767

768

769

770

771

772

773

774

775

776

777

778

779

780

781

782

783

784

785

786

787

and language concordance matter? Journal of General Internal Medicine, 25(11), 1172 -

1177. doi:10.1007/s11606-010-1424-8

Tsoh, J. Y., Sentell, T., Gildengorin, G., Le, G. M., Chan, E., Fung, L. C., . . Nguyen, T. T. (2016). Healthcare Communication Barriers and Self-Rated Health in Older Chinese American Immigrants. Journal of Community Health, 41(4), 741-752. doi:10.1007/s10900-015-0148-4

Villalobos, B. T., Bridges, A. J., Anastasia, E. A., Ojeda, C. A., Rodriguez, J. H., \& Gomez, D. (2016). Effects of language concordance and interpreter use on therapeutic alliance in Spanish-speaking integrated behavioral health care patients. Psychological Services, 13(1), 49-59. doi:10.1037/ser0000051

Walsh, J., Nguyen, T., Nguyen, L., Pasick, R., \& McPhee, S. J. (2009). Healthy Colon, Healthy Life (Ruot Lành, Song Khoe): patient and physician factors associated with colorectal cancer screening among Vietnamese Americans in a county medical care system. Journal of Health Care for the Poor and Underserved, 20(1), 74-89. doi:10.1353/hpu.0.0122

Wilson, E., Chen, A. H., Grumbach, K., Wang, F., \& Fernandez, A. (2005). Effects of limited English proficiency and physician language on health care comprehension. Journal of General Internal Medicine, 20(9), 800-806. doi:10.1111/j.1525-1497.2005.0174.x

Woloshin, S., Schwartz, L. M., Katz, S. J., \& Welch, H. G. (1997). Is language a barrier to the use of preventive services? Journal of General Internal Medicine, 12(8), 472-477.

Youdelman, M. K. (2008). The medical tongue: U.S. laws and policies on language access. Health Aff (Millwood), 27(2), 424-433. doi:10.1377/hlthaff.27.2.424

Zong, J., \& Batalova, J. (2015). The Limited English Proficient Population in the United States. 
Table 1. Characteristics of 38 Included Studies Examining Patient-Provider Language Concordance and Health Outcomes

\begin{tabular}{|c|c|c|c|c|c|}
\hline & $k$ & $\%$ & & $k$ & $\%$ \\
\hline $\begin{array}{l}\text { Study Characteristics } \\
\text { Year of publication }\end{array}$ & & & $\begin{array}{l}\text { Patient Characteristics (cont.) } \\
\text { Immigrant status }\end{array}$ & & \\
\hline $1985-2005$ & 9 & 24 & Reported & 14 & 37 \\
\hline 2006-2010 & 10 & 26 & Not reported & 24 & 63 \\
\hline 2011-2015 & 13 & 34 & Language spoken ${ }^{\mathrm{b}}$ & & \\
\hline 2016-2017 & 6 & 16 & Spanish & 28 & 74 \\
\hline Sample size & & & Chinese & 7 & 18 \\
\hline$<200$ & 8 & 21 & Vietnamese & 5 & 13 \\
\hline $200-999$ & 17 & 45 & Russian & 3 & 8 \\
\hline $1000-1999$ & 6 & 16 & Portuguese & 3 & 8 \\
\hline $2000-9999$ & 4 & 11 & Haitian Creole & 2 & 5 \\
\hline $10000-30000$ & 3 & 8 & No restriction & 3 & 8 \\
\hline Study design & & & Other languages $^{\mathrm{d}}$ & 1 & 3 \\
\hline Cross-sectional & 21 & 55 & & & \\
\hline Cohort & 13 & 34 & Providers Characteristics & & \\
\hline Intervention & 4 & 11 & Type & & \\
\hline Region & & & Physician & 21 & 55 \\
\hline Northeast & 11 & 29 & Physician or nurse & 7 & 18 \\
\hline Midwest & 1 & 3 & Physician and healthcare team & 3 & 8 \\
\hline South & 1 & 3 & Patient navigator & 2 & 5 \\
\hline West & 21 & 55 & Behavioral health care provider & 1 & 3 \\
\hline National & 2 & 5 & Usual source of care & 3 & 8 \\
\hline More than one & 2 & 5 & Not reported & 1 & 3 \\
\hline Healthcare setting & & & Race/ethnicity ${ }^{\mathrm{b}}$ & & \\
\hline General outpatient/primary care & 21 & 55 & Hispanic/Latino & 8 & 21 \\
\hline Inpatient & 1 & 3 & Asian & 6 & 16 \\
\hline Specialty clinic & 5 & 13 & African American/Black & 4 & 11 \\
\hline None (e.g., phone survey) & 5 & 13 & White & 7 & 18 \\
\hline \multirow[t]{2}{*}{ Other/multiple } & 6 & 16 & Other ${ }^{\mathrm{c}}$ & 3 & 8 \\
\hline & & & Not reported & 30 & 79 \\
\hline Patient Characteristics & & & & & \\
\hline Age $^{a}$ & & & Language Concordance Assessment & & \\
\hline Age $<65$ & 31 & 82 & Informant & & \\
\hline Not reported & 3 & 8 & Patient report & 14 & 37 \\
\hline Gender & & & Hospital records or third party & 3 & 8 \\
\hline Female $0-49 \%$ of sample & 3 & 8 & Multiple & 3 & 8 \\
\hline Female $50-100 \%$ of sample & 31 & 82 & Not reported/not clear & 18 & 47 \\
\hline Not reported & 4 & 11 & & & \\
\hline Race/ethnicity ${ }^{\mathrm{b}}$ & & & Outcome Assessment & & \\
\hline Hispanic/Latino & 21 & 55 & Informant & & \\
\hline Asian & 10 & 26 & Patient report & 135 & 67 \\
\hline African American/Black & 8 & 21 & Hospital records or third party & 68 & 33 \\
\hline White & 12 & 32 & Patient and provider report & 6 & 3 \\
\hline Otherc & 8 & 21 & & & \\
\hline Not reported & 12 & 32 & & & \\
\hline
\end{tabular}

Note. ${ }^{\text {aMean}}$ /median/largest range. ${ }^{\text {b}}$ Results presented as representation across all studies. ${ }^{~}$ Other category used in some studies to capture participants that did not fall a designated race/ethnicity category (e.g., multiracial participants) while other studies used the Other category as a catch-all term for participants that did not fall into the racial/ethnic category of the specific group being studied (e.g., White versus Other, including Black, Asian, etc.) dOther languages include Armenian, Cambodian, Farsi, Hmong, Tagalog, and Serbo-Croatian, each represented in $k=1$ study. ${ }^{~}$ Results presented at the level of individual outcomes, $n=203$. 
Table 2. Methodological Details for the 38 Included Studies Examining Patient-Provider Language Concordance and Health Outcomes

\begin{tabular}{|c|c|c|c|c|c|c|c|}
\hline Ref. & $\begin{array}{l}\text { First } \\
\text { author, } \\
\text { year }\end{array}$ & $\begin{array}{l}\text { Study setting, } \\
\text { characteristics }\end{array}$ & $\begin{array}{l}\text { Participant } \\
\text { characteristics }\end{array}$ & Language(s) & $\begin{array}{l}\text { Language } \\
\text { concordance } \\
\text { informant; } \\
\text { definition } \\
\end{array}$ & $\begin{array}{l}\text { Outcome domain; } \\
\text { informant; } \\
\text { description }\end{array}$ & $\begin{array}{l}\text { \# of outcomes } \\
\text { represented in } \\
\text { review, \# significant }\end{array}$ \\
\hline 1 & $\begin{array}{l}\text { Baker } \\
\text { (1998) }\end{array}$ & $\begin{array}{l}\text { Cross-sectional study } \\
\text { of patients visiting an } \\
\text { emergency department } \\
\text { in CA }\end{array}$ & $\begin{array}{l}N=457, \\
\text { median age }= \\
36, \% \text { female }= \\
69\end{array}$ & Spanish & $\begin{array}{l}\text { Patient report; not } \\
\text { needing an } \\
\text { interpreter }\end{array}$ & $\begin{array}{l}\text { Process; patient report; } \\
\text { interpersonal aspects of } \\
\text { care }\end{array}$ & 10,9 \\
\hline 2 & $\begin{array}{l}\text { Boudreau } \\
(2010)\end{array}$ & $\begin{array}{l}\text { Cross-sectional study } \\
\text { of patients visiting a } \\
\text { community health } \\
\text { clinic in MA }\end{array}$ & $\begin{array}{l}N=438, \text { most } \\
\text { populated age } \\
\text { range }=25-34, \\
\% \text { female }= \\
86.2\end{array}$ & $\begin{array}{l}\text { Spanish and } \\
\text { Other }\end{array}$ & $\begin{array}{l}\text { Patient report; What } \\
\text { language do you } \\
\text { speak with the } \\
\text { doctor or nurse of } \\
\text { your child? }\end{array}$ & $\begin{array}{l}\text { Process and provider } \\
\text { behavior; patient } \\
\text { report; quality of child } \\
\text { well-care }\end{array}$ & 8,0 \\
\hline 3 & $\begin{array}{l}\text { Chao } \\
(2015)\end{array}$ & $\begin{array}{l}\text { Prospective cohort } \\
\text { study of patients } \\
\text { visiting a safety net } \\
\text { primary care clinic in } \\
\text { CA }\end{array}$ & $\begin{array}{l}N=132, \text { mean } \\
\text { age }=56, \% \\
\text { female }=76.5\end{array}$ & $\begin{array}{l}\text { Spanish and } \\
\text { Chinese }\end{array}$ & $\begin{array}{l}\text { Patient report; how } \\
\text { well regular } \\
\text { physician spoke } \\
\text { Spanish/Cantonese? }\end{array}$ & $\begin{array}{l}\text { Patient behavior; } \\
\text { patient self; disclosure } \\
\text { of complementary } \\
\text { health approaches }\end{array}$ & 1,1 \\
\hline 4 & $\begin{array}{l}\text { Charlot } \\
(2015)\end{array}$ & $\begin{array}{l}\text { Prospective cohort } \\
\text { study of patients } \\
\text { visiting a community } \\
\text { health clinic in MA }\end{array}$ & $\begin{array}{l}N=1257, \text { most } \\
\text { populated age } \\
\text { range }=40-59, \\
\% \text { female }= \\
100\end{array}$ & $\begin{array}{l}\text { Spanish, } \\
\text { Vietnamese, } \\
\text { and Other }\end{array}$ & $\begin{array}{l}\text { Not reported; } \\
\text { patients and patient } \\
\text { navigators who } \\
\text { were able to } \\
\text { communicate in the } \\
\text { same language }\end{array}$ & $\begin{array}{l}\text { Provider behavior; } \\
\text { hospital records; time } \\
\text { to diagnostic resolution } \\
\text { for breast cancer and } \\
\text { cervical cancer } \\
\text { screening abnormalities }\end{array}$ & 8,2 \\
\hline 5 & $\begin{array}{l}\text { Clark } \\
(2004)\end{array}$ & $\begin{array}{l}\text { Prospective cohort } \\
\text { study of patients } \\
\text { visiting an internal } \\
\text { medicine or family } \\
\text { medicine clinic in NM }\end{array}$ & $\begin{array}{l}N=427, \text { mean } \\
\text { age }=48, \% \\
\text { female }=67\end{array}$ & Spanish & $\begin{array}{l}\text { Patient report; } \\
\text { whether physician } \\
\text { fluently spoke in } \\
\text { native language at } \\
\text { visit }\end{array}$ & $\begin{array}{l}\text { Process; patient and } \\
\text { provider report; } \\
\text { patient-provider } \\
\text { agreement about } \\
\text { recommended changes } \\
\text { in patient health } \\
\text { behavior }\end{array}$ & 6,2 \\
\hline 6 & $\begin{array}{l}\text { de } \\
\text { Bocanegra } \\
(2011)\end{array}$ & $\begin{array}{l}\text { Cross-sectional study } \\
\text { of patients visiting a } \\
\text { general } \\
\text { outpatient/primary care } \\
\text { or family } \\
\text { planning/reproductive } \\
\text { health clinic in CA }\end{array}$ & $\begin{array}{l}N=1589 \\
\text { mean age }=56, \\
\% \text { female }= \\
88.8\end{array}$ & Spanish & $\begin{array}{l}\text { Not reported; } \\
\text { clinician proficiency } \\
\text { in patient's primary } \\
\text { language }\end{array}$ & $\begin{array}{l}\text { Provider behavior and } \\
\text { clinical outcome; } \\
\text { hospital records; } \\
\text { reproductive health } \\
\text { counseling and } \\
\text { chlamydia testing }\end{array}$ & 10,3 \\
\hline
\end{tabular}


Detz (2014) Cross-sectional study of patients visiting a

$N=250$, mean $\quad$ Spanish safety net clinic in CA

female $=58$

Dunlap

(2015)

Prospective cohort

study of patients

visiting a pediatric

$N=177$, age $=$

$\mathrm{NR}, \%$ female

$=\mathrm{NR}$

surgery clinic in CA

Eamranond Retrospective cohort

(2009)

study of patients

visiting a general

outpatient/primary care

or community health

clinic in MA

10 Eamranond Retrospective cohort

(2011) study of patients

visiting a general

outpatient/primary care

or community health

clinic in MA

$11 \quad \begin{aligned} & \text { Fernández } \\ & \text { (2017) }\end{aligned}$

Cross-sectional study

of patients visiting an integrated care clinic in

MA

12 Fernandez (2011)

Cross-sectional study

of patients visiting an

integrated care clinic in MA

13 Gany (2007)

female $=62.6$
Randomized controlled trial of patients visiting a general outpatient/primary care age $=54.4, \%$

$\begin{array}{lll}N=306, \text { mean } & \text { Spanish } & \text { Not reported; } \\ \text { age }=52.6, \% & & \text { whether primary } \\ \text { female }=62.6 & & \text { care provider could }\end{array}$

$N=306$, mean

age $=52.6, \%$

female $=62.6$

Spanish

$$
\begin{aligned}
& \text { Converse } \\
& \text { Spanish }
\end{aligned}
$$

Not reported;

whether primary

care provider could

converse fluently in

Spanish

$$
N=3205 \text {, }
$$

mean age $=$

55.6 , \% female

$$
=46.6
$$

$N=252$, mean

age $=56.8, \%$

female $=71.8$

Spanish
Spanish

Not reported;

providers asked to

rate own Spanish

fluency

Patient report;

without using an

interpreter, how

well personal

physician speaks

patient's language?

Not reported;

provider asked to

assess language

abilities

Spanish and

populated age Chinese range $=34-64$

$\%$ female $=$
Patient behavior and

10,6

process; patient

report; interpersonal

aspects of care and

diabetes care

Process; patient report;

satisfaction and clinical

understanding

2,2$$
\text { understanding }
$$

Provider behavior;

\section{3,2}

hospital records;

lifestyle counseling

Clinical outcome;

hospital records;

7, 2

primary care screening

Patient behavior;

5,0

hospital records;

diabetes medication

nonadherence

Clinical outcome;

hospital records; poor

glycemic control

1,1

50.9
Process; patient report; $\quad 9,6$

satisfaction with

provider

communication/care 


\begin{tabular}{|c|c|c|c|c|c|c|c|}
\hline & & $\begin{array}{l}\text { clinic or emergency } \\
\text { department in NY }\end{array}$ & & & & & \\
\hline 14 & $\begin{array}{l}\text { Goncalves } \\
\text { (2013) }\end{array}$ & $\begin{array}{l}\text { Cross-sectional study } \\
\text { of patients visiting a } \\
\text { behavioral health clinic } \\
\text { in MA }\end{array}$ & $\begin{array}{l}N=1328, \text { most } \\
\text { populated age } \\
\text { range }=35-54, \\
\% \text { female }= \\
73.3\end{array}$ & Portuguese & $\begin{array}{l}\text { Not reported; any } \\
\text { Portuguese- } \\
\text { speaking patient } \\
\text { with a visit to the } \\
\text { Portuguese Mental } \\
\text { Health Program }\end{array}$ & $\begin{array}{l}\text { Clinical outcome; } \\
\text { hospital records; } \\
\text { adequate mental health } \\
\text { treatment }\end{array}$ & 3,1 \\
\hline 15 & $\begin{array}{l}\text { González } \\
\text { (2010) }\end{array}$ & $\begin{array}{l}\text { Cross-sectional study } \\
\text { of respondents from a } \\
\text { nationally- } \\
\text { representative survey }\end{array}$ & $\begin{array}{l}N=2921 \\
\text { mean ag }= \\
40.6, \% \text { female } \\
=46.6\end{array}$ & Spanish & $\begin{array}{l}\text { Patient report; } \\
\text { preference for } \\
\text { English or Spanish } \\
\text { and appointment } \\
\text { usually done in } \\
\text { English or Spanish }\end{array}$ & $\begin{array}{l}\text { Process; patient report; } \\
\text { confusion, frustration, } \\
\text { or language-related } \\
\text { poor quality ratings, } \\
\text { overall quality of care }\end{array}$ & 4,4 \\
\hline 16 & $\begin{array}{l}\text { Green } \\
(2005)\end{array}$ & $\begin{array}{l}\text { Cross-sectional study } \\
\text { of patients visiting a } \\
\text { community health } \\
\text { clinic in NY, MA, TX, } \\
\text { CA, or WA }\end{array}$ & $\begin{array}{l}N=2715 \\
\text { mean age }= \\
53.4, \% \text { female } \\
=67.5\end{array}$ & $\begin{array}{l}\text { Chinese and } \\
\text { Vietnamese }\end{array}$ & $\begin{array}{l}\text { Patient report; what } \\
\text { language did your } \\
\text { doctor or nurse } \\
\text { speak to you? }\end{array}$ & $\begin{array}{l}\text { Process; patient report; } \\
\text { communication and } \\
\text { visit ratings }\end{array}$ & 6,2 \\
\hline 17 & $\begin{array}{l}\text { Hacker } \\
(2012)\end{array}$ & $\begin{array}{l}\text { Retrospective cohort } \\
\text { study of patients } \\
\text { visiting a general } \\
\text { outpatient/primary care } \\
\text { clinic in MA }\end{array}$ & $\begin{array}{l}N=1425, \text { most } \\
\text { populated age } \\
\text { range }=70+, \% \\
\text { female }=61.1\end{array}$ & $\begin{array}{l}\text { Portuguese, } \\
\text { Haitian Creole, } \\
\text { Spanish, } \\
\text { Other/Unknown }\end{array}$ & $\begin{array}{l}\text { Not reported; } \\
\text { provider asked to } \\
\text { report language } \\
\text { fluency during } \\
\text { hiring process }\end{array}$ & $\begin{array}{l}\text { Clinical outcome; } \\
\text { hospital records; } \\
\text { diabetes-related health }\end{array}$ & 4,1 \\
\hline 18 & $\begin{array}{l}\text { Jacobs } \\
(2007)\end{array}$ & $\begin{array}{l}\text { Prospective cohort } \\
\text { study of patients in an } \\
\text { inpatient unit in IL }\end{array}$ & $\begin{array}{l}N=323, \text { mean } \\
\text { age }=48.4, \% \\
\text { female }=51.8\end{array}$ & Spanish & $\begin{array}{l}\text { Provider report and } \\
\text { objective testing; } \\
\text { providers reported } \\
\text { practicing in } \\
\text { Spanish-speaking } \\
\text { country who } \\
\text { indicated they } \\
\text { conducted the visit } \\
\text { in Spanish OR } \\
\text { scored proficient on } \\
\text { American Council } \\
\text { on the Teaching of } \\
\text { Foreign Languages } \\
\text { oral proficiency } \\
\text { interview }\end{array}$ & $\begin{array}{l}\text { Patient behavior, } \\
\text { provider behavior, } \\
\text { process, clinical } \\
\text { outcome; patient report } \\
\text { and hospital records; } \\
\text { resource utilization, } \\
\text { patient satisfaction, } \\
\text { emergency department } \\
\text { visits/hospitalizations } \\
\text { and adherence to } \\
\text { follow-up } \\
\text { appointments }\end{array}$ & 9,3 \\
\hline
\end{tabular}




\begin{tabular}{|c|c|c|c|c|c|c|c|}
\hline 19 & $\begin{array}{l}\text { Jaramillo } \\
(2016)\end{array}$ & $\begin{array}{l}\text { Prospective cohort } \\
\text { study of patients } \\
\text { visiting a pediatric } \\
\text { surgery clinic in CA }\end{array}$ & $\begin{array}{l}N=156, \text { age }= \\
\text { NR, } \% \text { female } \\
=\mathrm{NR}\end{array}$ & Spanish & $\begin{array}{l}\text { Other (bilingual } \\
\text { research assistant } \\
\text { coded interactions); } \\
\text { Spanish speaking } \\
\text { without an } \\
\text { interpreter }\end{array}$ & $\begin{array}{l}\text { Patient behavior and } \\
\text { process; patient report } \\
\text { and research assistant } \\
\text { coding; communication } \\
\text { and patient-initiated } \\
\text { questions }\end{array}$ & 4,2 \\
\hline 20 & Jih (2015) & $\begin{array}{l}\text { Cross-sectional study } \\
\text { of respondents from a } \\
\text { nationally- } \\
\text { representative survey }\end{array}$ & $\begin{array}{l}N=1884 \\
\text { mean age }= \\
53.2, \% \text { female } \\
=100\end{array}$ & $\begin{array}{l}\text { Spanish and } \\
\text { Chinese }\end{array}$ & $\begin{array}{l}\text { Patient report; } \\
\text { provider } \\
\text { communicated in } \\
\text { same language as } \\
\text { patient and patient } \\
\text { did not have } \\
\text { difficulty } \\
\text { understanding their } \\
\text { provider }\end{array}$ & $\begin{array}{l}\text { Clinical outcome; } \\
\text { patient } \\
\text { report; preventive care } \\
\text { services }\end{array}$ & 6,1 \\
\hline 21 & $\begin{array}{l}\text { Lasser } \\
(2005)\end{array}$ & $\begin{array}{l}\text { Cross-sectional study } \\
\text { of patients visiting a } \\
\text { general } \\
\text { outpatient/primary care } \\
\text { clinic in MA }\end{array}$ & $\begin{array}{l}N=28745, \\
\text { most populated } \\
\text { age range }= \\
18-40, \% \\
\text { female }=61.3\end{array}$ & $\begin{array}{l}\text { Portuguese, } \\
\text { Haitian Creole, } \\
\text { Spanish }\end{array}$ & $\begin{array}{l}\text { Not reported; } \\
\text { providers asked to } \\
\text { rate own } \\
\text { fluency/whether } \\
\text { they were a native } \\
\text { speaker }\end{array}$ & $\begin{array}{l}\text { Patient behavior; } \\
\text { hospital records; } \\
\text { missed appointment }\end{array}$ & 1,1 \\
\hline 22 & Lee (2002) & $\begin{array}{l}\text { Prospective cohort } \\
\text { study of patients } \\
\text { visiting an urgent care } \\
\text { clinic in } \mathrm{CO}\end{array}$ & $\begin{array}{l}N=536, \\
\text { median age }= \\
32, \% \text { female }= \\
65\end{array}$ & Spanish & $\begin{array}{l}\text { Not reported; } \\
\text { Spanish-Spanish } \\
\text { and English-English } \\
\text { speaking dyads }\end{array}$ & $\begin{array}{l}\text { Process; patient report; } \\
\text { satisfaction with } \\
\text { provider } \\
\text { communication/care }\end{array}$ & 24,11 \\
\hline 23 & $\begin{array}{l}\text { Leng } \\
(2011)\end{array}$ & $\begin{array}{l}\text { Randomized controlled } \\
\text { trial of patients visiting } \\
\text { a general } \\
\text { outpatient/primary care } \\
\text { clinic in NY }\end{array}$ & $\begin{array}{l}N=191, \text { age }= \\
\text { NR, } \% \text { female } \\
=\mathrm{NR}\end{array}$ & $\begin{array}{l}\text { Spanish and } \\
\text { Chinese }\end{array}$ & $\begin{array}{l}\text { Patient and provider } \\
\text { report; both patient } \\
\text { and provider } \\
\text { reported proficiency } \\
\text { and jointly decided } \\
\text { not to use an } \\
\text { interpreter }\end{array}$ & $\begin{array}{l}\text { Provider behavior and } \\
\text { clinical outcome; } \\
\text { hospital records; } \\
\text { receipt of referral for } \\
\text { tuberculin testing and } \\
\text { completion of } \\
\text { tuberculin testing }\end{array}$ & 2,0 \\
\hline 24 & $\begin{array}{l}\text { Manson } \\
(1988)\end{array}$ & $\begin{array}{l}\text { Retrospective cohort } \\
\text { study of patients } \\
\text { visiting a general } \\
\text { outpatient/primary care } \\
\text { clinic in NY }\end{array}$ & $\begin{array}{l}N=59, \text { mean } \\
\text { age }=55.8, \% \\
\text { female }=94.9\end{array}$ & Spanish & $\begin{array}{l}\text { Not reported; } \\
\text { patients with } \\
\text { providers who } \\
\text { spoke fluent or near } \\
\text { fluent Spanish }\end{array}$ & $\begin{array}{l}\text { Patient behavior; } \\
\text { hospital records; } \\
\text { medication adherence } \\
\text { and missing } \\
\text { appointments }\end{array}$ & 2,1 \\
\hline 25 & $\begin{array}{l}\text { Martin } \\
(2009)\end{array}$ & $\begin{array}{l}\text { Cross-sectional study } \\
\text { of respondents from a }\end{array}$ & $\begin{array}{l}N=20052 \\
\text { most populated } \\
\text { age range }=0-\end{array}$ & No restriction & $\begin{array}{l}\text { Patient report; usual } \\
\text { source of care }\end{array}$ & $\begin{array}{l}\text { Patient behavior and } \\
\text { process; primary care } \\
\text { experiences }\end{array}$ & 11,1 \\
\hline
\end{tabular}




\begin{tabular}{|c|c|c|c|c|c|c|c|}
\hline & & $\begin{array}{l}\text { 26nationally- } \\
\text { re27presentative survey }\end{array}$ & $\begin{array}{l}65, \% \text { female }= \\
\text { NR }\end{array}$ & & $\begin{array}{l}\text { speaks the same } \\
\text { language }\end{array}$ & & \\
\hline 26 & $\begin{array}{l}\text { Mehler } \\
(2004)\end{array}$ & $\begin{array}{l}\text { Retrospective cohort } \\
\text { study of patients } \\
\text { visiting a general } \\
\text { outpatient/primary care } \\
\text { clinic or emergency } \\
\text { department in CO }\end{array}$ & $\begin{array}{l}N=55, \text { mean } \\
\text { age }=65.4, \% \\
\text { female }=58.1\end{array}$ & Russian & $\begin{array}{l}\text { Not reported; } \\
\text { hospital record of } \\
\text { patient inability to } \\
\text { converse in English } \\
\text { matched with } \\
\text { Russian-speaking } \\
\text { resident }\end{array}$ & $\begin{array}{l}\text { Clinical outcome; } \\
\text { hospital } \\
\text { record; metabolic } \\
\text { control }\end{array}$ & 4,3 \\
\hline 27 & $\begin{array}{l}\text { Ngo- } \\
\text { Metzger } \\
(2007)\end{array}$ & $\begin{array}{l}\text { Cross-sectional study } \\
\text { of patients visiting a } \\
\text { community health } \\
\text { clinic in NY, MA, TX, } \\
\text { CA, or WA }\end{array}$ & $\begin{array}{l}N=2746, \\
\text { mean age }= \\
53.8, \% \text { female } \\
=66.7\end{array}$ & $\begin{array}{l}\text { Chinese and } \\
\text { Vietnamese }\end{array}$ & $\begin{array}{l}\text { Patient report; what } \\
\text { language did doctor } \\
\text { or nurse speak } \\
\text { during most recent } \\
\text { exam? }\end{array}$ & $\begin{array}{l}\text { Provider behavior and } \\
\text { process; patient report; } \\
\text { receipt of health } \\
\text { education and ratings } \\
\text { of interpersonal care } \\
\text { and satisfaction with } \\
\text { provider }\end{array}$ & 3,2 \\
\hline 28 & $\begin{array}{l}\text { Parker } \\
(2017)\end{array}$ & $\begin{array}{l}\text { Single group pre-post } \\
\text { intervention study of } \\
\text { patients visiting a } \\
\text { general } \\
\text { outpatient/primary care } \\
\text { clinic in CA }\end{array}$ & $\begin{array}{l}N=863, \text { most } \\
\text { populated age } \\
\text { range }=45-64, \\
\% \text { female }= \\
52.3\end{array}$ & Spanish & $\begin{array}{l}\text { Hospital record } \\
\text { data; provider-rated } \\
\text { fluency in Spanish } \\
\text { OR evidence from } \\
\text { utility data that } \\
\text { provider delivered } \\
\text { care in Spanish } \\
\text { without the aid of an } \\
\text { interpreter }\end{array}$ & $\begin{array}{l}\text { Clinical outcome; } \\
\text { hospital records; } \\
\text { glycemic control }\end{array}$ & 4,2 \\
\hline 29 & $\begin{array}{l}\text { Percac- } \\
\text { Lima } \\
(2012)\end{array}$ & $\begin{array}{l}\text { Single group pre-post } \\
\text { intervention study of } \\
\text { patients visiting a } \\
\text { community health } \\
\text { clinic in MA }\end{array}$ & $\begin{array}{l}N=91, \text { mean } \\
\text { age }=54, \% \\
\text { female }=100\end{array}$ & Serbo-Croatian & $\begin{array}{l}\text { Not reported; } \\
\text { bilingual patient } \\
\text { navigator matched } \\
\text { to identified Serbo- } \\
\text { Croatian patient }\end{array}$ & $\begin{array}{l}\text { Clinical outcome; } \\
\text { hospital records; } \\
\text { mammogram }\end{array}$ & 1,1 \\
\hline 30 & $\begin{array}{l}\text { Pérez- } \\
\text { Stable } \\
(1997)\end{array}$ & $\begin{array}{l}\text { Cross-sectional study } \\
\text { of patients visiting a } \\
\text { general } \\
\text { outpatient/primary care } \\
\text { clinic in CA }\end{array}$ & $\begin{array}{l}N=236, \text { most } \\
\text { populated } \\
\text { range }=65-94, \\
\% \text { female }= \\
54.2\end{array}$ & Spanish & $\begin{array}{l}\text { Hospital record } \\
\text { data; provider report } \\
\text { of Spanish ability, } \\
\text { rated understanding } \\
\text { of Spanish } \\
\text { language, minimum } \\
\text { frequency of } \\
\text { Spanish use in }\end{array}$ & $\begin{array}{l}\text { Process and clinical } \\
\text { outcome; patient } \\
\text { report; } \\
\text { physical/psychological } \\
\text { functioning and well- } \\
\text { being, health } \\
\text { perceptions pain, and } \\
\text { satisfaction with } \\
\text { provider }\end{array}$ & 12,7 \\
\hline
\end{tabular}


clinical interactions of $4 \mathrm{x}$ a week

\begin{tabular}{|c|c|c|c|c|c|c|c|}
\hline 31 & $\begin{array}{l}\text { Rostanski } \\
\text { (2016) }\end{array}$ & $\begin{array}{l}\text { Retrospective cohort } \\
\text { study of patients } \\
\text { visiting an emergency } \\
\text { department in NY }\end{array}$ & $\begin{array}{l}N=48, \text { mean } \\
\text { age }=67.9, \% \\
\text { female }=62.3\end{array}$ & $\begin{array}{l}\text { Spanish, } \\
\text { Russian, and } \\
\text { Other }\end{array}$ & $\begin{array}{l}\text { Not reported; } \\
\text { provider asked to } \\
\text { report language } \\
\text { fluency }\end{array}$ & $\begin{array}{l}\text { Provider behavior; } \\
\text { hospital records; stroke } \\
\text { mimic treatment and } \\
\text { time to stroke mimic } \\
\text { treatment }\end{array}$ & 2,0 \\
\hline 32 & $\begin{array}{l}\text { Schenker } \\
(2010)\end{array}$ & $\begin{array}{l}\text { Cross-sectional study } \\
\text { of patients visiting an } \\
\text { integrated care clinic in } \\
\text { CA }\end{array}$ & $\begin{array}{l}N=363, \text { mean } \\
\text { age }=58.4, \% \\
\text { female }=62.3\end{array}$ & No restriction & $\begin{array}{l}\text { Patient report; } \\
\text { without using an } \\
\text { interpreter, how } \\
\text { well personal } \\
\text { physician speaks } \\
\text { patient's language? }\end{array}$ & $\begin{array}{l}\text { Process; patient report; } \\
\text { patient satisfaction with } \\
\text { provider } \\
\text { communication/care }\end{array}$ & 10,3 \\
\hline 33 & $\begin{array}{l}\text { Sentell } \\
(2013)\end{array}$ & $\begin{array}{l}\text { Cross-sectional study } \\
\text { of respondents from a } \\
\text { statewide survey in CA }\end{array}$ & $\begin{array}{l}N=539, \text { most } \\
\text { populated } \\
\text { range }=50-64, \\
\% \text { female }= \\
50.9\end{array}$ & Not reported & $\begin{array}{l}\text { Patient report; } \\
\text { provider spoke same } \\
\text { non-English } \\
\text { language }\end{array}$ & $\begin{array}{l}\text { Clinical outcome; } \\
\text { patient report; } \\
\text { colorectal cancer } \\
\text { screen }\end{array}$ & 1,0 \\
\hline 34 & $\begin{array}{l}\text { Traylor } \\
(2010)\end{array}$ & $\begin{array}{l}\text { Cross-sectional study } \\
\text { of patients visiting an } \\
\text { integrated care clinic in } \\
\text { CA }\end{array}$ & $\begin{array}{l}N=17750, \\
\text { mean age }= \\
60.1, \% \text { female } \\
=50\end{array}$ & Spanish & $\begin{array}{l}\text { Not reported; } \\
\text { provider asked to } \\
\text { report language } \\
\text { fluency during } \\
\text { hiring process }\end{array}$ & $\begin{array}{l}\text { Patient behavior; } \\
\text { hospital records; } \\
\text { cardiovascular disease } \\
\text { medication adherence }\end{array}$ & 4,1 \\
\hline 35 & Tsoh (2016) & $\begin{array}{l}\text { Cross-sectional study } \\
\text { of patients recruited } \\
\text { from lay health } \\
\text { workers' social } \\
\text { networks in CA }\end{array}$ & $\begin{array}{l}N=665, \text { mean } \\
\text { age }=62.2, \% \\
\text { female }=81\end{array}$ & Chinese & $\begin{array}{l}\text { Patient report; } \\
\text { language usually } \\
\text { spoken by provider } \\
\text { is Chinese? }\end{array}$ & $\begin{array}{l}\text { Clinical outcome; } \\
\text { patient report; rated } \\
\text { health }\end{array}$ & 1,0 \\
\hline 36 & $\begin{array}{l}\text { Villalobos } \\
(2016)\end{array}$ & $\begin{array}{l}\text { Cross-sectional study } \\
\text { of patients visiting a } \\
\text { general } \\
\text { outpatient/primary care } \\
\text { clinic in AR }\end{array}$ & $\begin{array}{l}N=458, \text { mean } \\
\text { age }=41.4, \% \\
\text { female }=84.1\end{array}$ & Spanish & $\begin{array}{l}\text { Not reported; } \\
\text { bilingual providers }\end{array}$ & $\begin{array}{l}\text { Process; patient report; } \\
\text { therapeutic alliance }\end{array}$ & 1,0 \\
\hline 37 & $\begin{array}{l}\text { Walsh } \\
(2009)\end{array}$ & $\begin{array}{l}\text { Cross-sectional study } \\
\text { of patients visiting a } \\
\text { general } \\
\text { outpatient/primary care } \\
\text { clinic in CA }\end{array}$ & $\begin{array}{l}N=808, \text { mean } \\
\text { age }=60.8, \% \\
\text { female }=64.7\end{array}$ & Vietnamese & Not reported & $\begin{array}{l}\text { Clinical outcome; } \\
\text { patient report; } \\
\text { colorectal cancer } \\
\text { screen }\end{array}$ & 3,0 \\
\hline
\end{tabular}




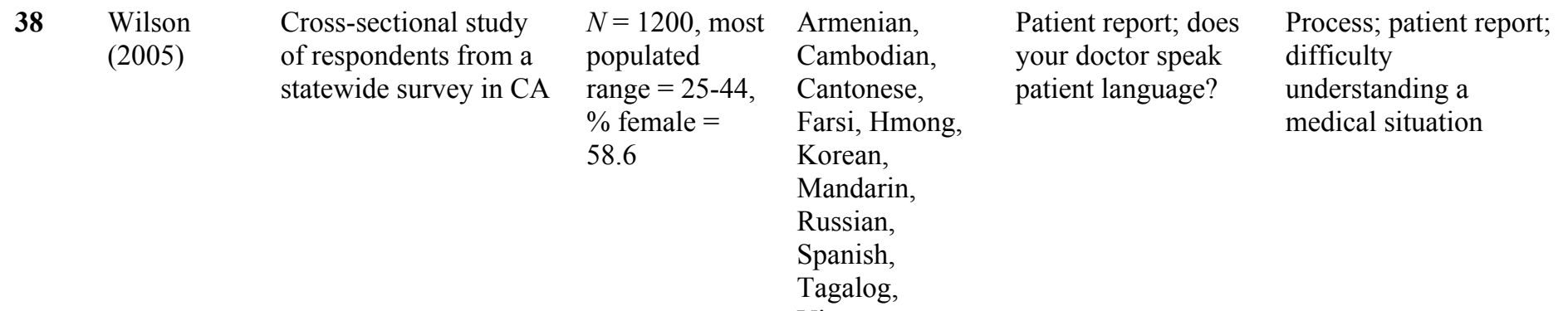



Provider Language Concordance and Health Outcomes

\begin{tabular}{ll}
\hline $\begin{array}{l}\text { First author, } \\
\text { year }\end{array}$ & Major findings \\
\hline Baker (1998) & $\begin{array}{l}\text { LC was positively associated with patient } \\
\text { satisfaction scores on most to } \\
\text { all interpersonal aspects of care (compared } \\
\text { to LD-I and LD, respectively). }\end{array}$ \\
$\begin{array}{l}\text { Boudreau } \\
(\mathbf{2 0 1 0 )}\end{array}$ & $\begin{array}{l}\text { LC was not associated with reports of } \\
\text { higher-quality well-child care among Latin } \\
\text { parents. }\end{array}$ \\
Chao (2015) & $\begin{array}{l}\text { LC was positively associated with } \\
\text { disclosure of complementary health } \\
\text { approaches among patients with diabetes. }\end{array}$
\end{tabular}

Charlot

(2015)

Clark (2004)

de Bocanegra (2011)

Detz (2014)

LC was positively associated with timelier resolution ( $<90$ days) of cervical cancer screening abnormalities for all language groups. No differences were detected for post-90 day resolutions for screening abnormalities in either the cervical cancer or breast cancer screening abnormality groups for any language group.

LC was positively associated with likelihood of agreement about exercise, but negatively associated with likelihood of agreement about medications. No differences were detected for other agreement outcomes (stress, diet, smoking, weight).

LC was positively associated with the provision of reproductive health counseling. No differences were detected for sexually transmitted infection risk assessment or chlamydia testing.

LC was positively associated with more favorable ratings on most interpersonal aspects of care and one measure of diabetes self-care (foot care). No differences were found for ratings on discrimination or other aspects of diabetes self-care (healthy eating, self-monitoring, and medication adherence).
Dunlap
(2015)

\section{Limitations}

Cross-sectional study, limited to CA, English-English dyads included in language concordant group

Low parent response rate, organizational cultural competency may have created a ceiling effect, cross-sectional study, limited to MA, English-English dyads included in language concordant group

Only asked about disclosure of complementary health approaches within the past month, limited to CA, EnglishEnglish dyads included in language concordant group

Limited to MA, English-English dyads included in language concordant group, did not confirm language concordance as occurring (patient navigators matched to patients so that they could speak the same language)

Convenience sample, limited to NM, English-English dyads included in language concordant group

Providers did not consistently document language needs of patients in medical charts (therefore could not extend analysis to Spanish-speaking patients who saw an English-speaking provider without an interpreter), cross-sectional study, limited to $\mathrm{CA}$, did not confirm language concordance as occurring (provider asked to rate fluency) Diabetes self-care based on patient selfreport, cross-sectional study with convenience sample, limited to CA, did not confirm language concordance as occurring (provider asked to rate fluency)

Convenience sample, limited to CA, very specific study setting (Hispanic Clinic for Pediatric Surgery) which may confound unique effects of language concordance, did not confirm language concordance as 
Eamranond (2009)

Eamranond (2011)

Fernández (2017)

\section{Fernandez} (2011)

Gany (2007)

\section{Goncalves (2013)}

González (2010)
LC was positively associated with provision of diet and physical activity counseling. No differences were detected for smoking counseling.

LC was negatively associated with colorectal cancer screens and tetanus vaccinations. No differences were detected for hyperlipidemia screens, diabetes screens, mammographies, breast cancer screens, or influenza vaccinations. LC was not associated with diabetes medication nonadherence.

LC was negatively associated with poor glycemic control (HbA1c $>9 \%$ ).

LC was positively associated with satisfaction with provider communication/care (composite score). Language concordance was positively associated with satisfaction with most provider communication/care scores in subdomain analyses (e.g., clarity). LC was positively associated with one measure of receiving adequate treatment $(>$ 8 outpatient psychotherapy visits or $>4$ outpatient visits of which at least one was a psychopharmacological visit). No differences were detected for two other measures of adequate treatment (ER use among those with a visit for a psychiatric diagnosis, receipt of inpatient care for a psychiatric diagnosis).

LC was negatively associated with ratings of frustration, confusion, or perceptions of receiving lower quality of care due to an accent or English language ability. LC was positively associated with overall quality of care. occurring (assumed through a visit through the Hispanic Clinic for Pediatric Surgery)

Small sample size, effects could be due to differences in provider adherence to recommendations in counseling rather than language concordance, limited to MA, did not confirm language concordance as occurring (providers were natives of Latin America or Spain)

Small sample size, limited to MA, did not confirm language concordance as occurring (providers were natives of Latin America or Spain)

Misclassification of LEP was possible because classification is based on administrative data for patient's language preference (i.e., patients could be proficient in English and could have carried out the visit in English), only captures adherence for newly prescribed medication and may not capture those who refused medication in the visit, cross-sectional study, limited to $\mathrm{CA}$, did not confirm language concordance as occurring (provider asked to rate fluency)

Cross-sectional study, limited to CA, English-English dyads included in language concordant group Limited to NY, English-English dyads included in language concordant group, did not confirm language concordance as occurring (provider asked to rate fluency)

Cross-sectional study, limited to MA, very specific study setting (Portuguese Mental Health Program) which may confound unique effects of language concordance, no explicit information given on how EnglishEnglish dyads were handled, did not confirm language concordance as occurring (assumed through a visit to the Portuguese Mental Health Program)

Outcomes based on last clinical encounter but language concordance determined by asking patient to consider what language their usual appointment visit is conducted in (last clinical encounter may not have been language concordant); cross-sectional 
Green (2005) LC was negatively associated with having unasked questions about their care or mental health. No differences were detected for three other measures of communication (enough time to explain reason for visit, how well provider explained things, given enough information about health) or overall visit rating.

Hacker LC was negatively associated with \# of (2012) diabetes-related ER visits and overall \# of diabetes-related hospitalizations/ER visits. No differences were detected for $\mathrm{HbAlc}$, \# of non-diabetes related ER visits, or \# of diabetes-related hospitalizations.

Jacobs (2007) LC was positively associated with patient satisfaction with providers and satisfaction with hospital stay and positively associated with \# of ED visits after discharge. No differences were found for patient satisfaction with nursing, patient's adherence to follow-up appointment, patient's length of hospital stay, resource overutilization (provider-ordered specialty consults and provider-ordered radiology tests), or \# of hospitalizations after discharge.

Jaramillo LC was positively associated with ratings of (2016) communication and \# of patient-initiated questions. No differences were found for ratings of trust or perceived discrimination.

Jih (2015) LC was negatively associated with CRC screening among Asians but not Latinos. No differences were detected for mammography or influenza vaccination for Asians or Latinos.

Lasser (2005) LC was negatively associated with missed appointments.

Lee (2002) LC was positively associated with 4 of 8 , and 7 or 8 , satisfaction measures (compared to interpretation done through family members and ad-hoc interpreters, respectively). No differences were found study, English-English dyads included in language concordant group

Cross-sectional study with convenience sample

Ratio of language concordant physicians to language group was different across languages, records were examined six months later for laboratory readings which may not be a sufficient amount of time to detect changes, limited to MA Limited to IL

Convenience sample, limited to CA, very specific study setting (Hispanic Clinic for Pediatric Surgery) which may have confounded the unique effects of language concordance, English-English dyads included in language concordant group Low response rate, use of preventive services based on patient self-report, patients asked to confirm seeing a provider in the past two years but study was unable to confirm if this was the usual source of care, cross-sectional study, limited to CA Cross-sectional study, limited to MA, English-English dyads included in language concordant group, did not confirm language concordance as occurring (provider asked to rate fluency or native speaking status, provider elected to not use an interpreter) Low survey completion/return rate, limited to $\mathrm{CO}$, English-English dyads included in language concordant group, no information on language concordance informant 
when LC was compared to interpretation done through telephone interpreters.

Leng (2011) No differences were detected for provision of referral for tuberculin test nor completion of tuberculin test.

$\begin{array}{ll}\text { Manson } & \text { LC was negatively associated with missing } \\ \text { (1988) } & \text { appointments. No differences were detected } \\ & \text { for medication adherence. }\end{array}$

Martin LC was positively associated with lack of (2009) difficulty contacting their usual source of care after-hours. No differences were detected for other primary care experiences (going to USC for new or ongoing health problems, going to USC preventive health care, going to USC for referrals, USC asks about other treatments, USC is difficult to contact by phone, USC has office hours, USC shows respect, USC asks patient on help on deciding on treatment, USC explains options to patient).

Mehler LC was positively associated with (2004) improvements in LDL, HbAlc, and diastolic blood pressure readings. No differences were detected for systolic blood pressure readings.

Ngo-Metzger LC was positively associated with receipt of (2007)

Parker (2017) LC was positively associated with glycemic control (LDL $<100 \mathrm{mg} / \mathrm{dL})$. No differences were detected for poor glycemic control control (systolic blood pressure $<140 \mathrm{~mm}$

Percac-Lima LC was positively associated with (2012) control $(\mathrm{HbA} 1 \mathrm{c}<8 \%)$ and good LDL $(\mathrm{HbA} 1 \mathrm{c}>9 \%)$ or good blood pressure $\mathrm{Hg}$ ).

health education and ratings of interpersonal care. No differences were detected for ratings of satisfaction with provider. mammographies.
Cross-sectional study, limited to NY, English-English dyads included in language concordant group

Detected nontherapeutic serum levels (measure of medication nonadherence) may have been due to provider nonadherence to prescribing therapeutic levels or differences in drug bioavailability, limited to NY, small sample size, no information on language concordance informant

Cross-sectional study, English-English dyads included in language concordant group

Limited to CO, small sample size, did not confirm language concordance as occurring (ethnically Russian patients matched with new internist from Russia), limited to single Russian internist

Limited to those with a visit to primary care in the last month, cross-sectional study

Misclassification of Latinos with LEP possible, limited to $\mathrm{CA}$

Limited to MA, small sample size, limited to a single patient navigator, did not confirm language concordance as occurring (Serbo-Croatian-speaking patients matched with a single Serbo-Croatian patient navigator from Bosnia), limited to a single Serbo-Croatian-speaking provider 
Pérez-Stable (1997)

\section{Rostanski (2016)}

\section{Schenker (2010)}

Traylor
(2010)
LC was positively associated with physical and psychological functioning and wellbeing (overall domains) and better health perceptions. LC was negatively associated with pain (overall domain). No differences were detected for certain subdomains or for patient satisfaction.

Walsh (2009)

No differences were detected for stroke mimic treatment or time to stroke mimic treatment.

LC was negatively associated with 3 of 10 ratings of poor provider communication/care (provider not understanding problems with carrying out treatment regimen, lack of confidence in provider, perception of poor treatment due to language). No differences were detected for 7 other measurements.

Sentell (2013) No differences were detected for completed colorectal cancer screens.

LC was positively associated with adherence to all CVD medications (composite score). No differences were detected for individual analyses of medication adherence (adherence to diabetes, cholesterol, or hypertension medications).

Tsoh (2016) No differences were detected for self-rated health.

Villalobos No differences were detected for (2016) therapeutic alliance.
Wilson (2005) LC was negatively associated with having a problem understanding a medical situation because it was not explained in the patient's language.
Low survey completion rate, retrospective review of medical records is a suboptimal method of measuring health care utilization in an open system, Medical Outcomes Study measures not validated for use in a Spanish-speaking sample, cross-sectional study, limited to CA, English-English dyads included in language concordant group Misclassification of stroke mimics possible, limited to NY, small sample size, EnglishEnglish dyads included in language concordant group, did not confirm language concordance as occurring (provider asked to rate fluency)

Cross-sectional study, limited to CA

Cancer screening history based on patient self-report, sample with LEP small, crosssectional study, limited to CA, did not report provider type Cross-sectional study, limited to CA, no explicit information given on how EnglishEnglish dyads were handled, did not confirm language concordance as occurring (provider asked to rate fluency)

Cross-sectional study, limited to CA

Cross-sectional study, limited to AR, did not provide information on language concordance informer (providers were considered bilingual but no information provided for how that was determined) Medical comprehension and adverse medication events based on patient selfreport, cross-sectional study, limited to CA, no explicit information given on how English-English dyads were handled, no information on language concordance informant,

Cross-sectional study, limited to CA

Note. $\mathrm{LC}=$ language concordance; $\mathrm{LD}-\mathrm{I}=$ language discordant, including interpreter use; $\mathrm{LD}=$ language discordance; $\mathrm{CA}=$ California; $\mathrm{MA}=$ Massachusetts; $\mathrm{NM}=\mathrm{New}$ Mexico; $\mathrm{NY}=\mathrm{New}$ York; $\mathrm{TX}=$ Texas; $\mathrm{WA}=$ Washington; $\mathrm{IL}=$ Illinois; $\mathrm{CO}=$ Colorado; $\mathrm{AR}=$ Arkansas; $\mathrm{NR}=$ not reported; ED = emergency department; ER = emergency room. 
Table 4. Summary of Findings Regarding Associations of Patient-Provider Language Concordance with Patient Behaviors, Provider Behaviors, Interpersonal Processes of Care, and Clinical Outcomes

\begin{tabular}{|c|c|c|c|c|}
\hline & $\begin{array}{l}\text { Association in } \\
\text { Favor of LC }\end{array}$ & $\begin{array}{l}\text { Association Not } \\
\text { in Favor of LC }\end{array}$ & No Association & Total \\
\hline \multirow[b]{2}{*}{ Patient behaviors $(k=9)^{\mathrm{a}}$} & $n(\%)$ & $n(\%)$ & $n(\%)$ & $n$ \\
\hline & $6(26.1)$ & $\mathbf{0}(\mathbf{0})$ & 17 (73.9) & 23 \\
\hline Medication adherence $(k=4)$ & 1 & 0 & 10 & 11 \\
\hline Other adherence $(k=4)$ & 3 & 0 & 3 & 6 \\
\hline Other patient behaviors $(k=3)$ & 2 & 0 & 4 & 6 \\
\hline Provider behaviors $(k=8)$ & $8(27.6)$ & $\mathbf{0}(\mathbf{0})$ & $21(72.4)$ & 29 \\
\hline Timeliness of treatment $(k=2)$ & 2 & 0 & 7 & 9 \\
\hline Risk factor assessment $(k=2)$ & 1 & 0 & 3 & 4 \\
\hline Provision of services $(k=5)$ & 5 & 0 & 9 & 14 \\
\hline Overutilization of resources $(k=1)$ & 0 & 0 & 2 & 2 \\
\hline Interpersonal processes of care $(k=17)$ & $49(50.5)$ & $1(1)$ & 47 (48.5) & 97 \\
\hline Interpersonal style $(k=11)$ & 16 & 0 & 12 & 28 \\
\hline $\begin{array}{l}\text { Communication/information quality } \\
(k=10)\end{array}$ & 12 & 0 & 6 & 18 \\
\hline Satisfaction $(k=8)$ & 7 & 0 & 7 & 14 \\
\hline $\begin{array}{l}\text { Listening skills/feeling understood } \\
(k=4)\end{array}$ & 5 & 0 & 3 & 8 \\
\hline Shared decision-making $(k=4)$ & 1 & 0 & 4 & 5 \\
\hline $\begin{array}{l}\text { Spending enough time with patient } \\
(k=3)\end{array}$ & 1 & 0 & 3 & 4 \\
\hline $\begin{array}{l}\text { Other interpersonal processes of care } \\
(k=6)\end{array}$ & 7 & 1 & 12 & 20 \\
\hline Clinical outcomes $(k=17)$ & $16(29.6)$ & $4(7.4)$ & $34(63)$ & 54 \\
\hline Assessments and procedures $(k=8)$ & 1 & 3 & 19 & 23 \\
\hline Risk factor control $(k=4)$ & 6 & 0 & 4 & 10 \\
\hline ED visit/hospitalization $(k=3)$ & 1 & 1 & 4 & 6 \\
\hline Other clinical outcomes $(k=4)$ & 8 & 0 & 7 & 15 \\
\hline All outcomes & $79(38.9)$ & $5(2.5)$ & $119(58.6)$ & 203 \\
\hline
\end{tabular}

Note. Total number of studies $(k)=38 . \mathrm{LC}=$ language concordance; $\mathrm{ED}=$ emergency department. ${ }^{\mathrm{a}}$ Number of studies examining subdomains (e.g., medication adherence) do not sum to the total number of studies for the global domain (e.g., patient behaviors) because several studies examined more than one subdomain (e.g., a study examining medication adherence and other adherence would be counted twice). 


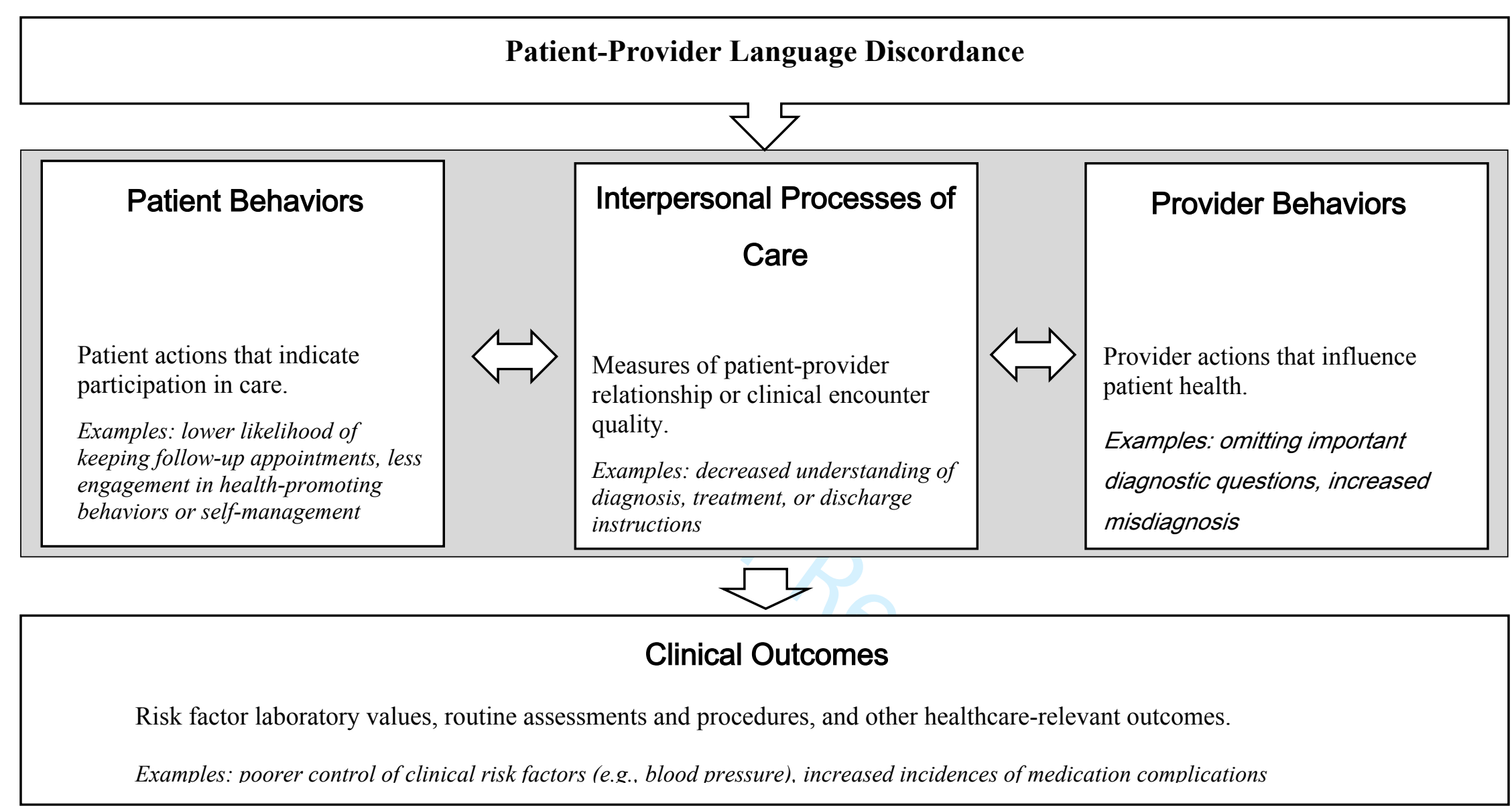




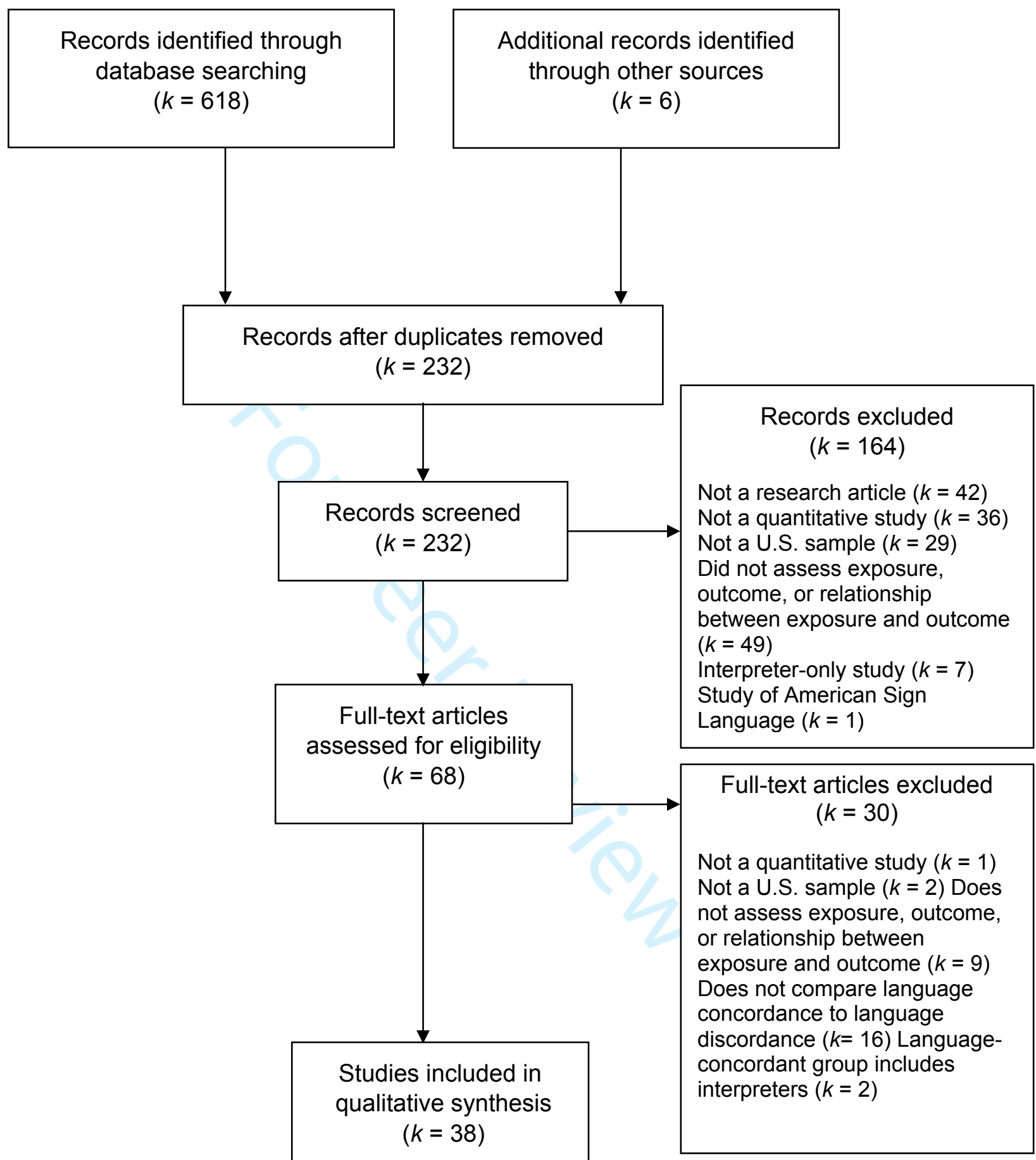




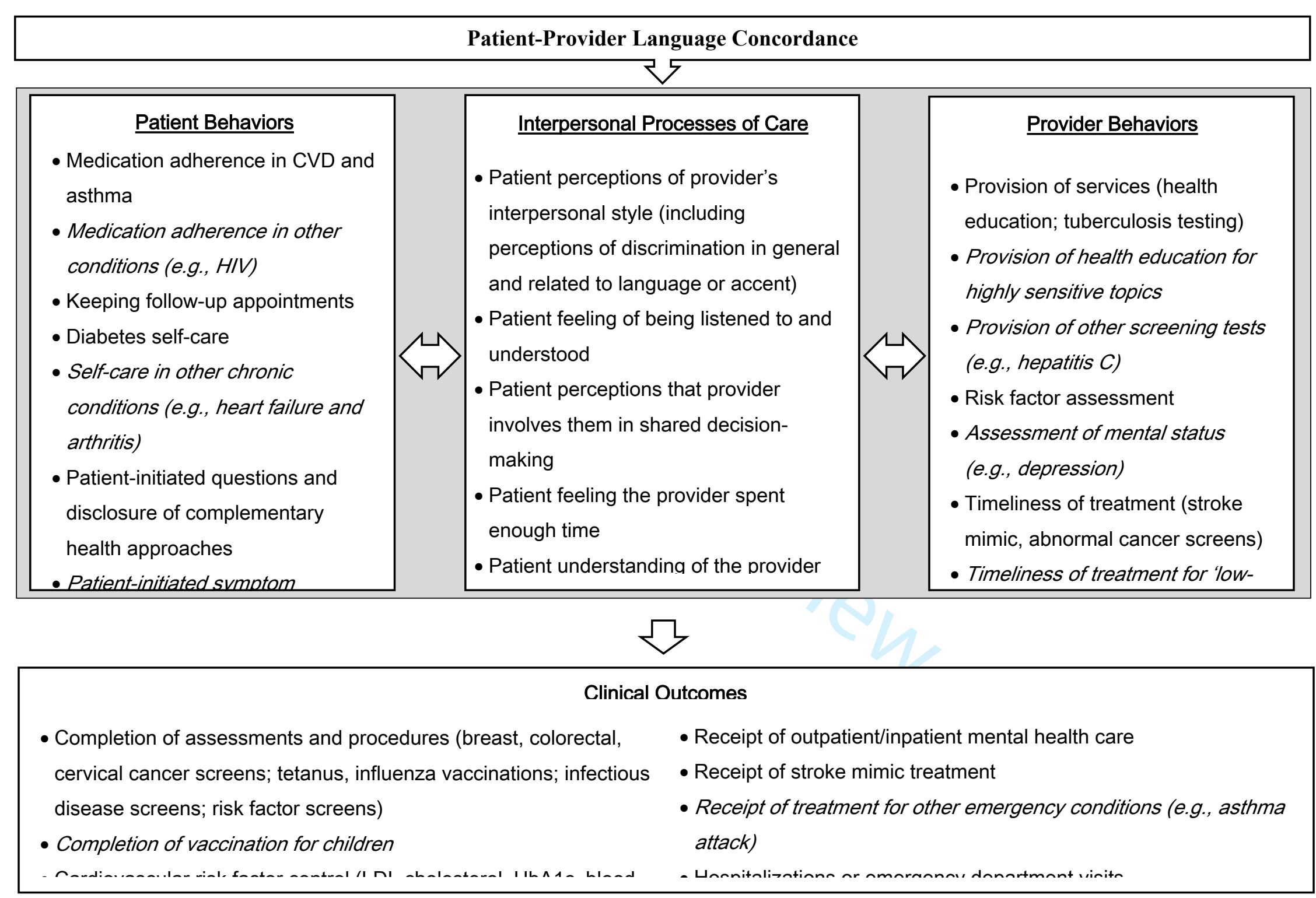




\section{Figure Captions}

1. Figure 1. Guiding conceptual framework adapted from Kilbourne, Switzer, Hyman, Crowley-Matoka, and Fine (2006) illustrating how patient-provider language concordance may affect patient behaviors, provider behaviors, interpersonal processes of care, and clinical outcomes, potentially contributing to poorer health. The conceptual framework guides categorization of health outcomes for this review.

2. Figure 2. Flow chart of study selection process.

3. Figure 3. Evidence map illustrating the state of the literature examining patient-provider language concordance and patient behaviors, provider behaviors, interpersonal processes of care, and clinical outcomes by sampling topics included in this review. Topics in italics are gaps in knowledge for future research. 
Supplemental Table 1. Summary of Findings Regarding Associations of Patient-Provider Language Concordance with Patient Behaviors, Provider Behaviors, Interpersonal Processes of Care, and Clinical Outcomes from Subanalysis of 90 Associations Excluding English-English Dyads

\begin{tabular}{|c|c|c|c|c|}
\hline & $\begin{array}{c}\text { Association in } \\
\text { Favor of LC } \\
\end{array}$ & $\begin{array}{l}\text { Association Not } \\
\text { in Favor of LC }\end{array}$ & No Association & Total \\
\hline \multirow[b]{2}{*}{ Patient behaviors $(k=5)^{\mathrm{a}}$} & $n(\%)$ & $n(\%)$ & $n(\%)$ & $n$ \\
\hline & 2 (16.6) & $\mathbf{0}(\mathbf{0})$ & $10(83.3)$ & 12 \\
\hline \multirow{6}{*}{$\begin{array}{l}\text { Provider behaviors }(\boldsymbol{k}=\mathbf{4}) \\
\quad \text { Risk factor assessment }(k=1) \\
\text { Provision of services }(k=3) \\
\text { Overutilization of resources }(k=1)\end{array}$} & 1 & 0 & 6 & 7 \\
\hline & 1 & 0 & 4 & 5 \\
\hline & $6(46.2)$ & $\mathbf{0}(\mathbf{0})$ & $7(53.8)$ & 13 \\
\hline & 1 & 0 & 1 & 2 \\
\hline & 5 & 0 & 4 & 9 \\
\hline & 0 & 0 & 2 & 2 \\
\hline Interpersonal processes of care $(k=8)$ & $16(51.6)$ & $\mathbf{0}(\mathbf{0})$ & $15(48.4)$ & 31 \\
\hline Interpersonal style $(k=3)$ & 4 & 0 & 4 & 8 \\
\hline $\begin{array}{l}\text { Communication/information quality } \\
(k=5)\end{array}$ & 7 & 0 & 3 & 10 \\
\hline Satisfaction $(k=4)$ & 3 & 0 & 3 & 6 \\
\hline $\begin{array}{l}\text { Listening skills/feeling understood } \\
(k=1)\end{array}$ & 1 & 0 & 1 & 2 \\
\hline Shared decision-making $(k=2)$ & 1 & 0 & 1 & 2 \\
\hline $\begin{array}{l}\text { Spending enough time with patient } \\
(k=2)\end{array}$ & 0 & 0 & 2 & 2 \\
\hline $\begin{array}{l}\text { Other interpersonal processes of care } \\
(k=1)\end{array}$ & 0 & 0 & 1 & 1 \\
\hline Clinical outcomes $(k=10)$ & 7 (20.6) & $4(11.8)$ & $23(67.6)$ & 34 \\
\hline Assessments and procedures $(k=5)$ & 1 & 3 & 14 & 18 \\
\hline Risk factor control $(k=3)$ & 5 & 0 & 4 & 9 \\
\hline ED visit/hospitalization $(k=2)$ & 1 & 1 & 3 & 5 \\
\hline Other clinical outcomes $(k=2)$ & 0 & 0 & 2 & 2 \\
\hline All outcomes & $31(34.4)$ & $4(4.4)$ & $55(61.1)$ & 90 \\
\hline
\end{tabular}

Note. Total number of studies $(k)=20 . \mathrm{LC}=$ language concordance; $\mathrm{ED}=$ emergency department. ${ }^{\mathrm{N}}$ Number of studies examining subdomains (e.g., medication adherence) do not sum to the total number of studies for the global domain (e.g., patient behaviors) because several studies examined more than one subdomain (e.g., a study examining medication adherence and other adherence would be counted twice). 